\title{
An Optimal Corporate Governance Framework for Internationalization: A case study
}

Abbas Toosi ${ }^{1}$ Assistant Professor, Department of Private and Economic Law, Faculty of Law and Politics, Allameh Tabataba'i University, Tehran, Iran.

Abbas Ahmadi Assistant Professor, Department of Management, Payam Noor University, Tehran, Iran.

Mohammad Reza Seyyed Hashemi Touloun Ph.D Student of Oil and Gas International Contracts Managment, Faculty of Law and Politics, Allameh Tabataba'i University, Tehran, Iran (Corresponding Author).

\section{Abstract}

An analysis of the international environment of oil industry and its developments shows that the oil industry sector will remain as an essential component of both energy and world economy. However, it will be a quite different environment with different characteristics; meaning, it will be an industry with different technologies, challenges, requirements, opportunities, and players all calling for a change in the business model and corporate-based leading of players on the basis of the environmental changes. One fundamental reform which the National Iranian Oil Company needs to adopt is internationalization in order to adapt to the upcoming environment. A primary step in this regard will be changing the framework of corporate leadership compatible to the market and oil industry domain. The purpose of this article is to present an optimal internationalized model of corporate leadership for the N.I.O.C. based on the grounded theory. Having analyzed the interviews, the final framework was developed. Findings show that the optimal model includes fundamental changes along the macro-corporate leadership and provids a balance between business and non-business goals so that in the long run the best performance can be materialized. To reach this end, internal and external mechanisms of corporate leadership at the N.I.O.C. must be changed. The most important changes in the internal mechanisms will cover ownership pattern, structure of board of directors and its committees, internal and external controls, and the business conduct bylaw. The most significant changes in the external mechanisms must occur in the statute law of the N.I.O.C., legal supervisions independent of this company and independent auditing. The optimal framework will bring about such outcomes as raising foreign capital, access to international capabilities and technology transfer, ability to impact international political-economic relations and developing various capabilities arising from international activities.

Keywords: Corporate Governance, Corporate Leadership Framework, Internationalization, Corporate Leadership Mechanisms, Oil Industry General Policy.

\footnotetext{
1. toosi@atu.ac.ir

2. abbasahmadi@atu.ac.ir

3.m.r.s.hashemi@atu.ac.ir
} 


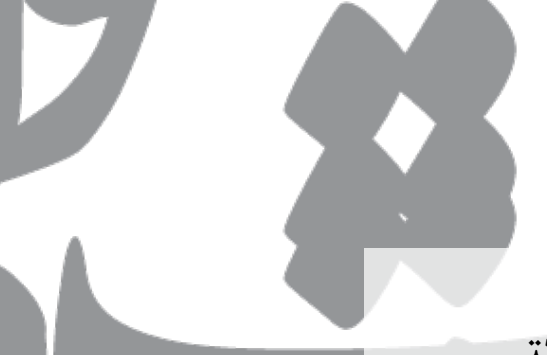

عنوان مقاله: تدوين جارجوب مطلوب راهبرى شركتى براى بين المللى شدن: مطالعه موردى

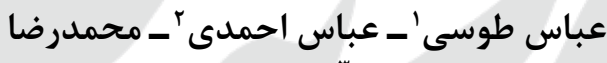

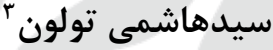

مقاله بثوهشى

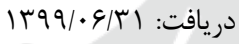

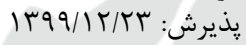

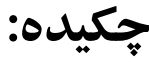

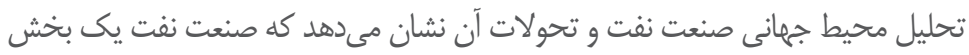

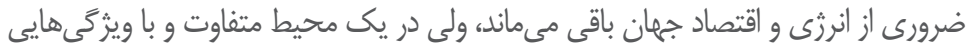

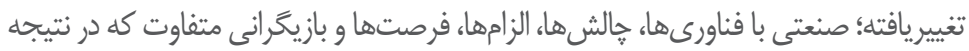

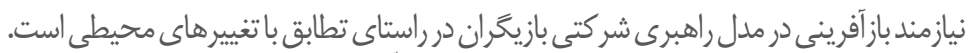

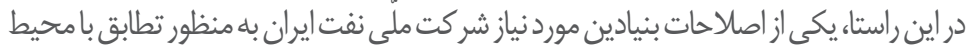

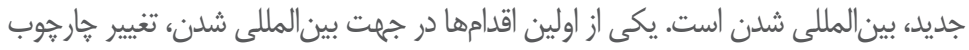

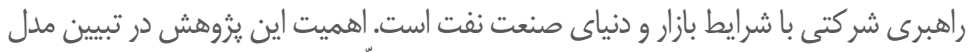

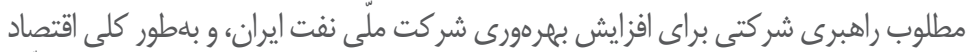

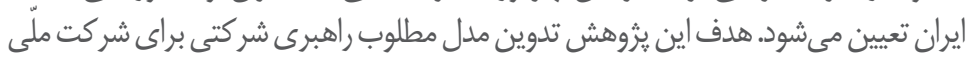

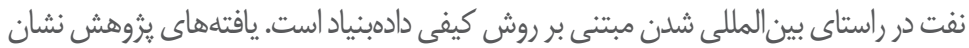

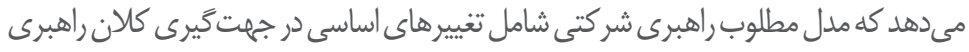

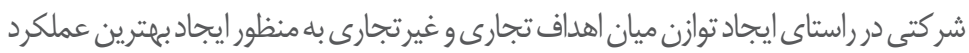

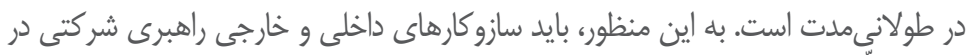

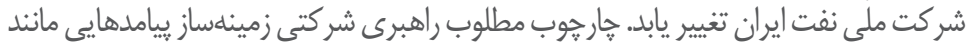

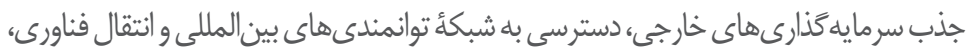

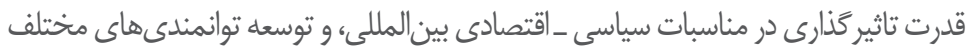

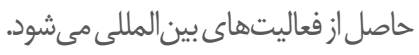

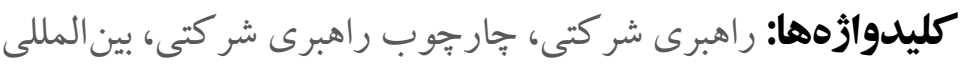

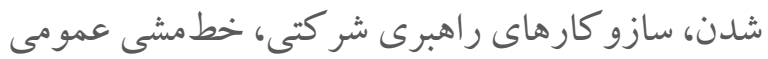

$$
\text { صنعت نفت }
$$

1. استاديار كروه حقوق خصوصى و اقتصادى، دانشكده حقوق و علوم سياسى، دانشكاه علامه طباطبايى، تهر ان، toosi@atu.ac.ir

abbasahmadi@ut.ac.ir

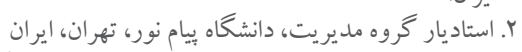

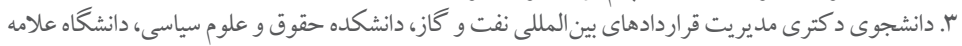
m.r.s.hashemi@atu.ac.ir

طباطبايى، تهران، ايران (نويسنده مسئول). 


\section{مقدمه}

راهبرى شركتى شامل فعاليتهاى متنوعى است كه با مديريت شركتها مرتبط است. اين امر

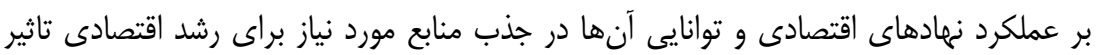
مى كذارد. با توجه به اهميت راهبرى شركتى، در عمل يثوهش جامعى براى بررسى تاثير تغييرهاى

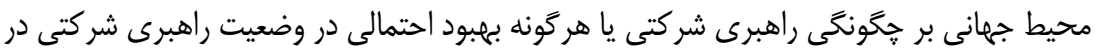
ايران، كه ممكن است تحت تاثير تغييرهاى جهانى ايجاد شود، انجام نشده است. همجنين، تاكنون هيج يزوهش تجربى جامعى در مورد مدل مطلوب راهبرى شركتى در صنعت نفت ايران انجام

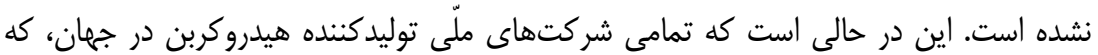
فعاليتهاى خود رادر خارج از كشور خود از طريق فرايند بين المللىسازى گسترش دادهاند، از طريق تدوين و بكارگيرى الخوى بومى راهبرى شركتى به اين مههم دست يافتهاند (Heinrich, 2005). يافته هاى يثوهشهاى ييشين نشان مىدهد كه از زيرساختهاى اصلى براى ييادهسازى

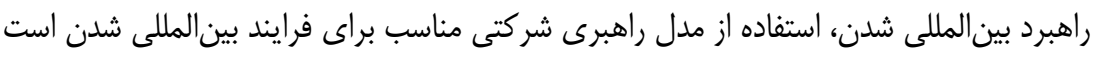

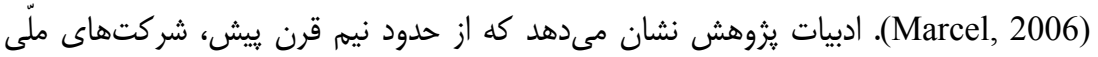
نفت با بكارگيرى مدل راهبرى شركتى مناسب و كسب قدرت در بخشهايى كه فاقد آن بودهاند

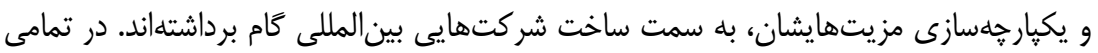

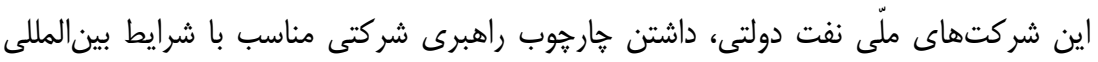

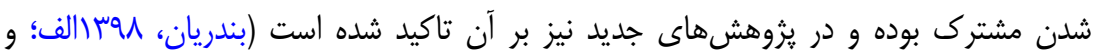
(Kumar \& Reshma, 2018; Marcel, 2016; Guzman et al., 2019; Mishra, 2015 در حالى است كه در دو دهه كذشته ديدكاههاى متفاوتى در رابطه با وضعيت صنعت نفت ايران مطرح گرديده كه نكته مورد اجماع همه ديدكاهها، نامطلوب بودن شرايط موجود و ضرورت تحول

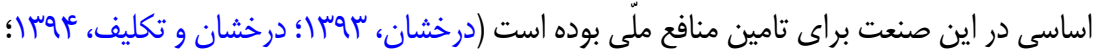
بندريان، Vوس الف؛ و Banasadegh et al., 2020 . براى حركت به سمت شر ايط مطلوب، ضرورت دارد اين صنعت بدون ييشداورى مورد آسيبشناسى قرار گيرد. در ساليان اخير، اين صنعت بيشتر

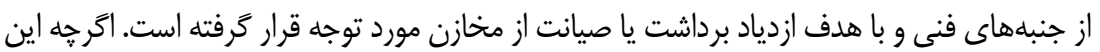
جنبههاى فنى در مقام خود داراى اهميت است، اما بدون نخاه نقادانه به ساختار صنعت نفت و مباحثى 
همجّون سازمان اجر ايى، برنامهريزى، نظارت، منابع انسانى، هزينههاى مبادلاتى، تراز كاز، و اساسنامه

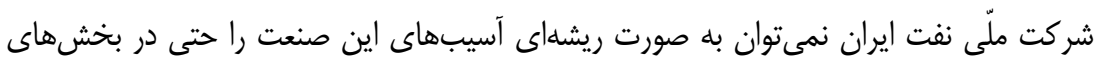

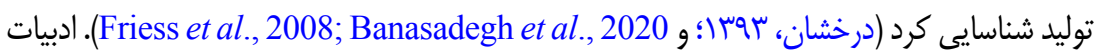

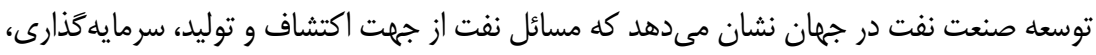

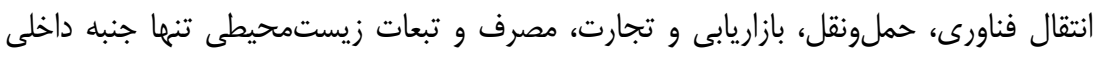

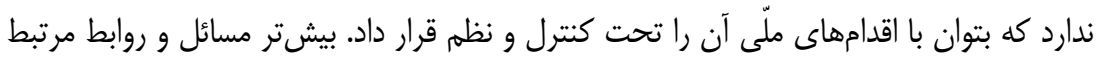

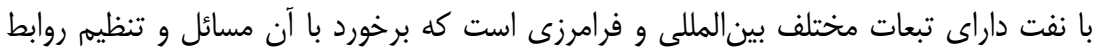
مستلزم يك نظه بينالمللى است (Marcel, 2016; Stevens, 2015). از طرف ديخر، محيط كسبوكار جهانى صنعت نفت در سالهاى اخير شاهد تغييرهاى كستردهاى بوده است. اين شرايط باعث مىشود كه شركتها و بازيخران اصلى صنعت نفت نقان

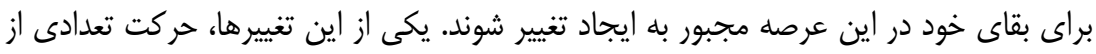

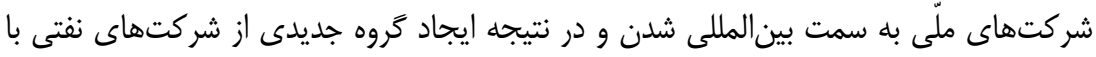

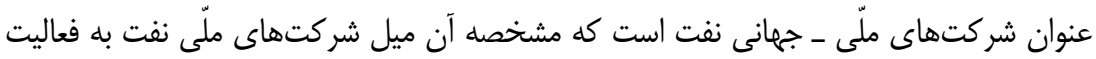

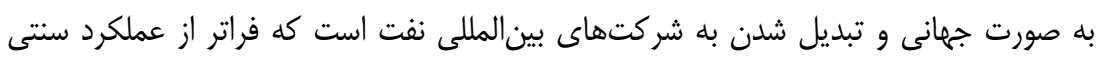

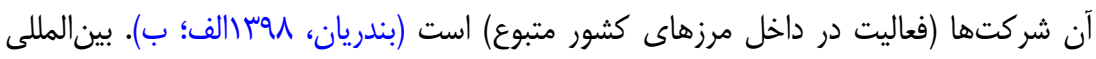

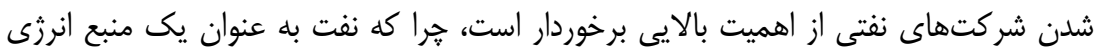

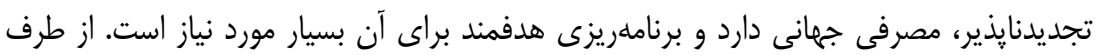

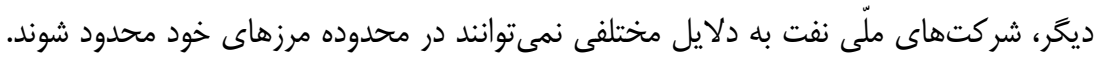

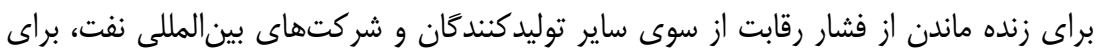

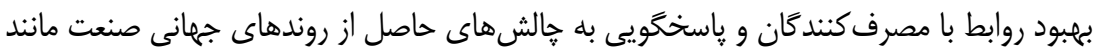

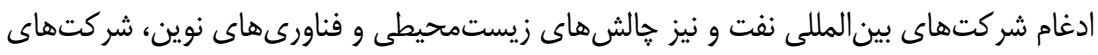

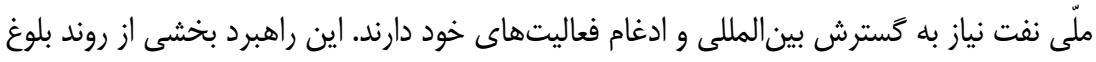

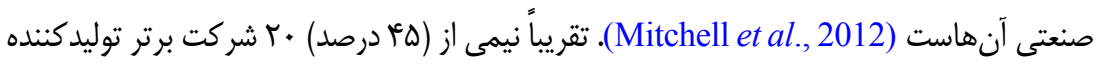

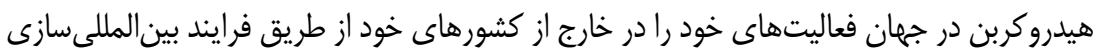

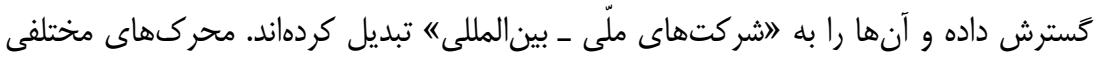

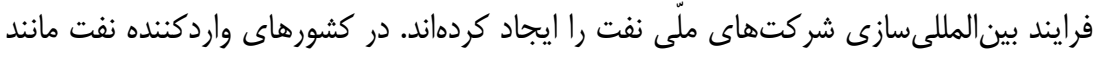

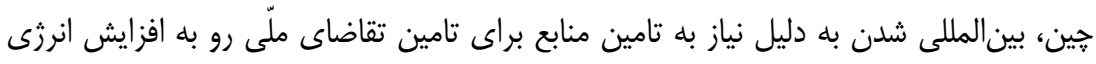

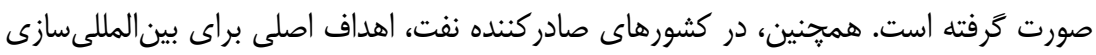


متنوعتر است. اين ممكن است شامل امنيت بازارها، دسترسى به منابع هيدروكربنى بسيار جذاب

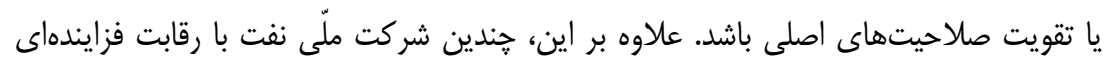

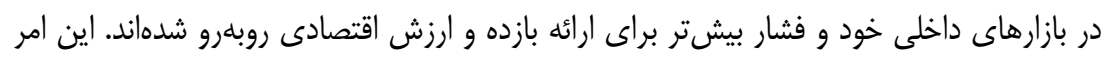

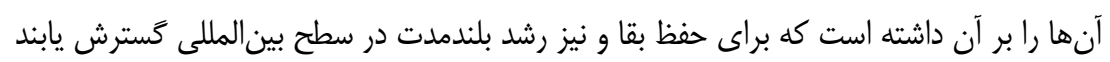

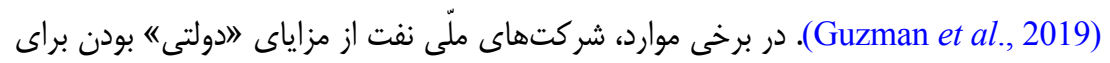

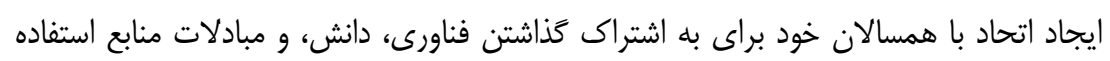

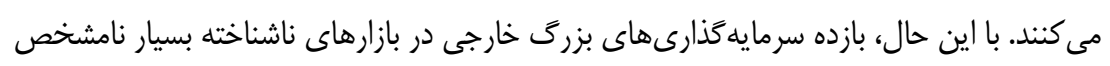

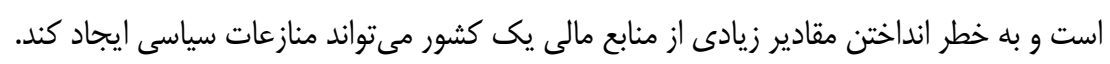

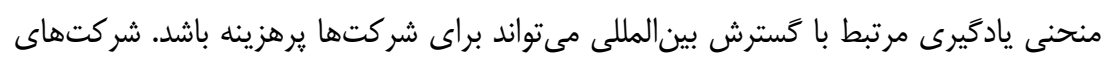

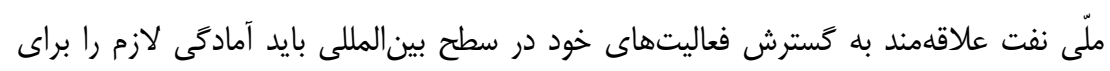

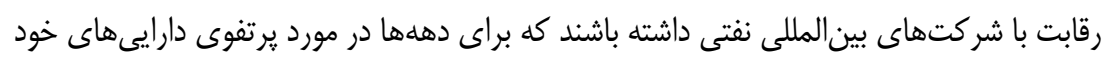

مذاكره و مديريت كرداند و داراى تجربيات ارزشمندى هستند (Guzman et al., 2019).

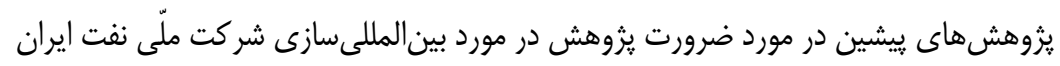

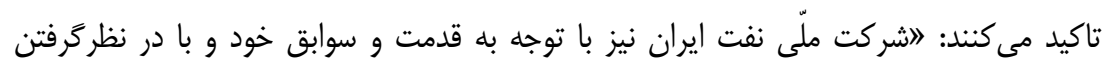

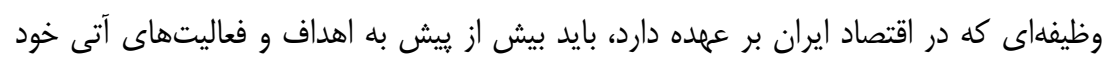

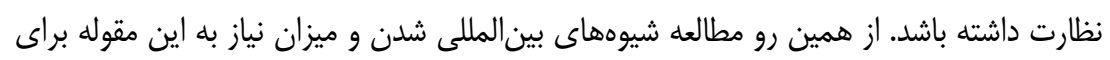

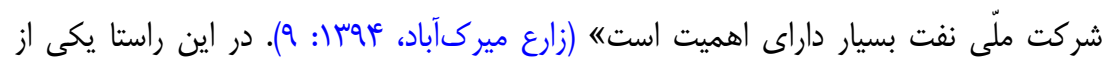

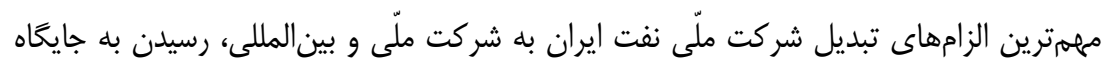

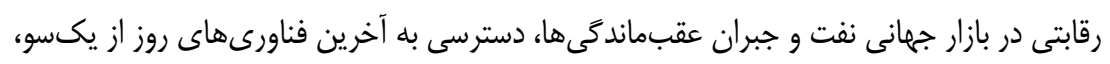

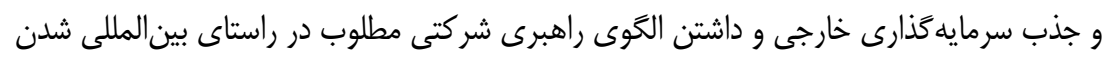

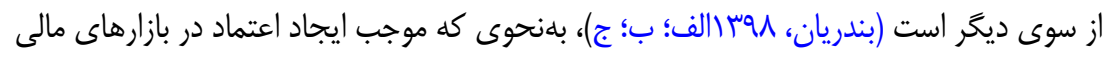

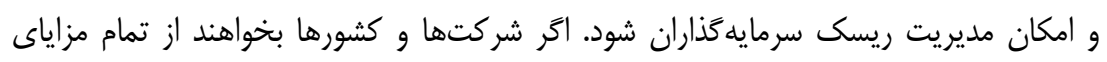

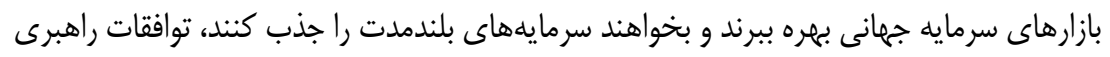

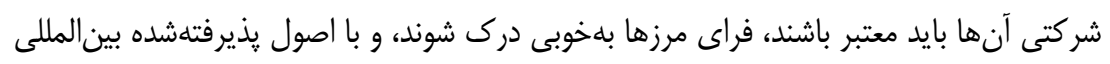

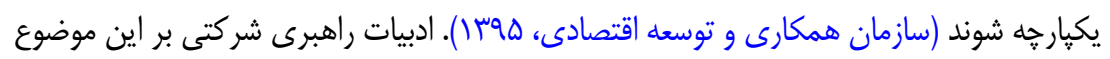

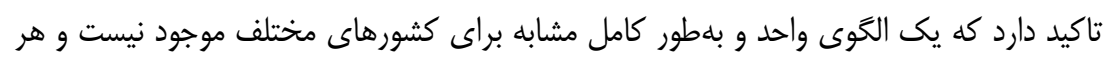

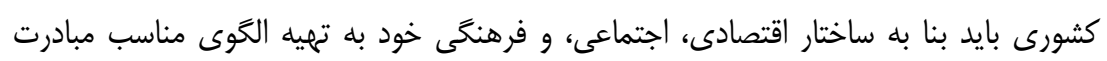

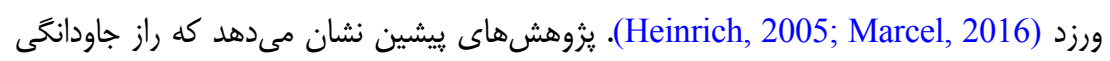


و كاميابى شركتهاى معروف و خوشنام در برخوردارى آنها از رعايت اصول راهبرى شركتى و برخوردارى از سازوكارهاى راهبرى شركتى كارامد نهفته است. با سقوط شركت انرون و موسسها

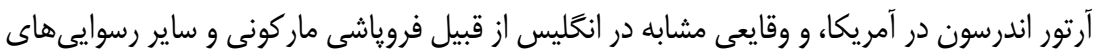
بزرى در آغاز قرن بيستويكم، راهبرى شركتى بهطور فزايندهاى مهم شده است. يزوهش حاضر

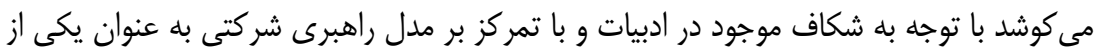

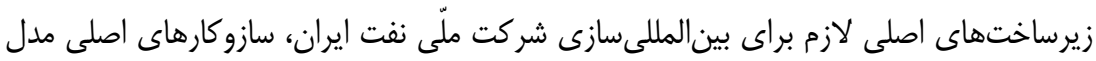

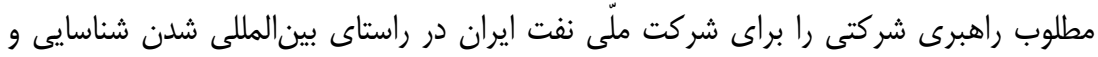
تبيين نمايد.

\section{مبانى نظرى ثيخوهش

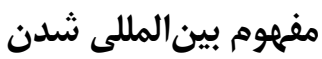

يديده بينالمللى شدن توسط يزوهشكَران بسيارى مورد مطالعه قرار كَرفته و منجر به اين

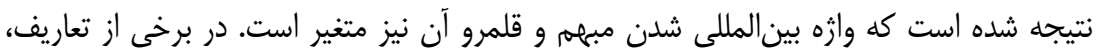

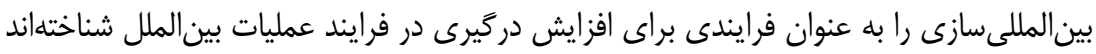

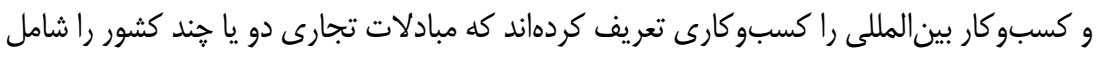

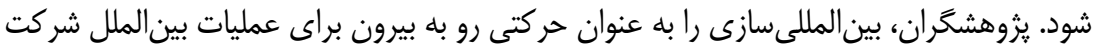

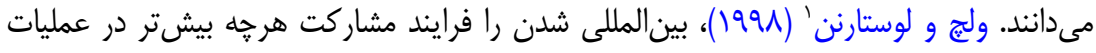

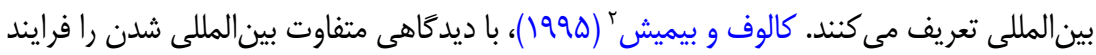
انطباق عمليات شركت (راهبرد، ساختار، و منابع) با محيطهاى بينالمللى تعريف مى كنند. البته

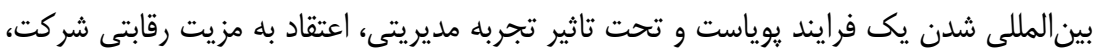

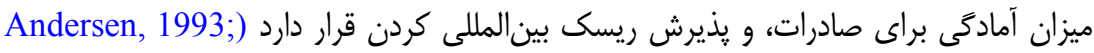

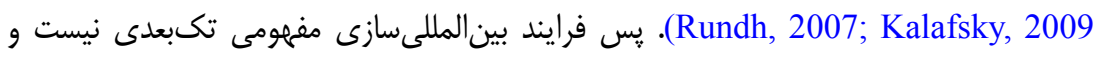

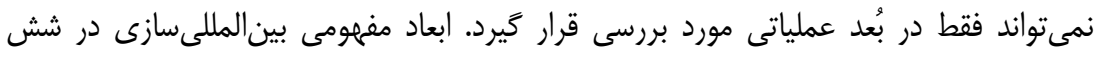
بُعد توسعه يافته است: (. روشهاى عمليات خارجى (طريقه ورود، راهبرد ورود)؛ ז. بازار (كجا؟)؛ بران

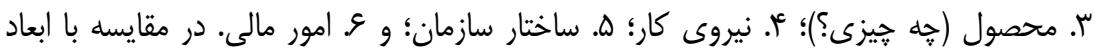

1. Welch \& Luostarinen

2. Calof \& Beamish 
اشارهشده محصول، نيروى انسانى، ساختار سازمانى، و امور مالى براى رشد هر شركت لازم است،

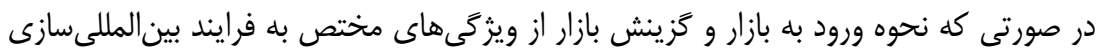

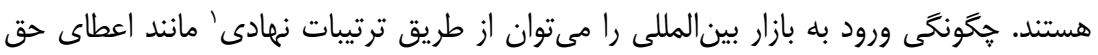
امتياز، صادرات، و سرمايهكذارى خارجى انتخاب كرد. كزينش بازار نيز مكانى رانى را كه عمليات

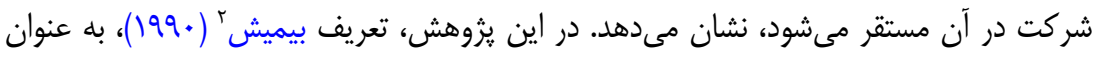
تعريف مفهومى از بينالمللىسازى مورد استفاده قرار مى

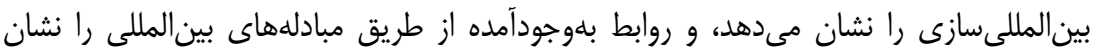

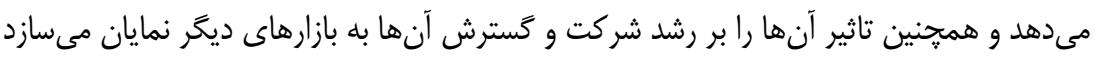

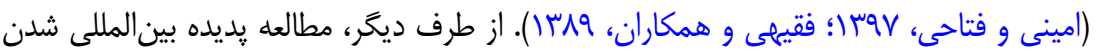

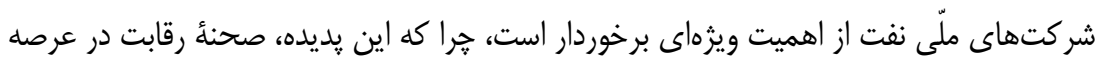
صنعت نفت را تغيير داده و باعث حذف برخى بازيخران قبلى و ظهور گروه جديدى از بازيخران نفتى شده است. يك اصل راهبردى در صنعت نفت جهانى كه توسط بازيخران مختلفى در صنعت نفت به اثبات

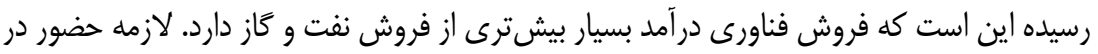

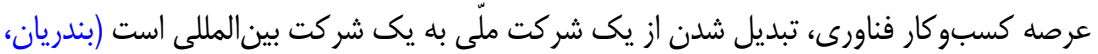

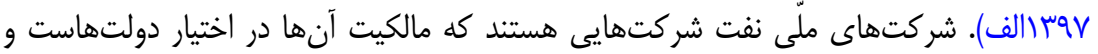
شر كتهاى بينالمللى نفتى شركتهايىاند كه فعاليتهاى عظيم بينالمللى دارند و مالكيت آنها در اختيار سرمايهذاران بخش خصوصى است. هر دو اين شركتها امروزه به عنوان مهمترين

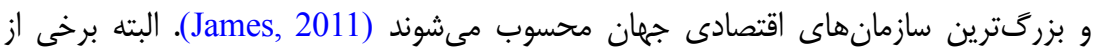
صاحبنظران اعتقاد دارند نام اشركتهاى بين المللى نفتى"ه كمى گمراه كننده است، زيرا امروزه

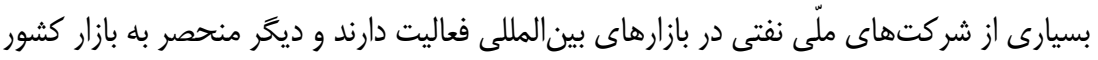

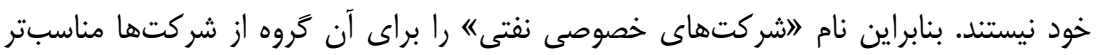
مىدانند (Tordo et al., 2011). البته در اين يزوهش مطابق با ادبيات از وازه بينالمانلى استفاده

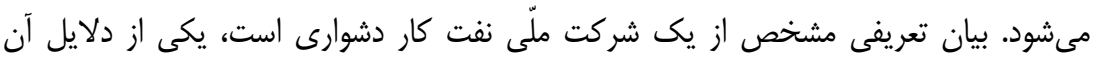

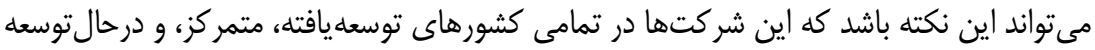

1. Institutional Arrangements

2. Beamish

3. International Oil Companies (IOCs) 
بلهور مشابه ظاهر شدهاند. دليل ديخر آن است كه برخى از شركتها مانند استات اويل' نروز،

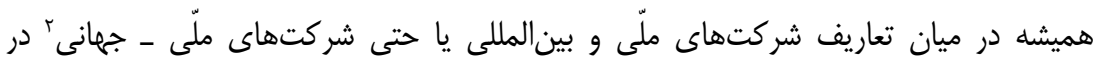

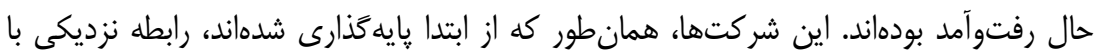

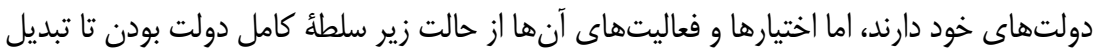

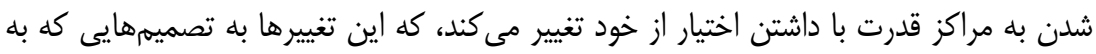

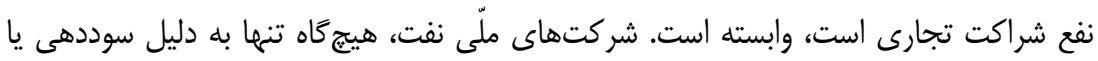

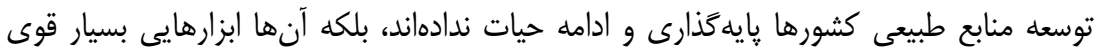

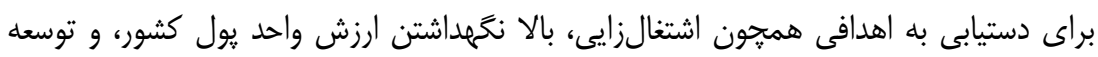

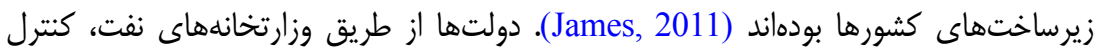
ذخاير هيدروكربنى كشور را در اختيار دارند و به عنوان مالك ذخاير (شرايط قراردادهاى اكتشاف التهاف

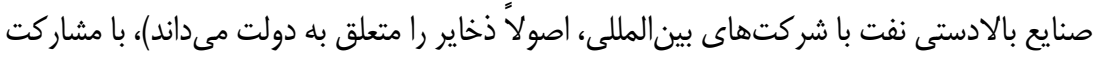

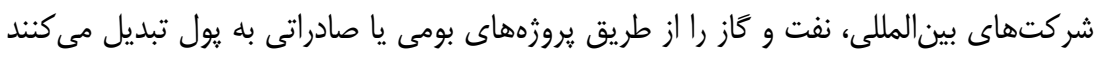

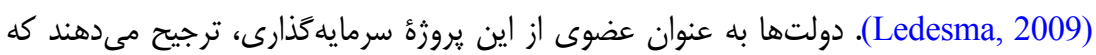
يك شركت ملّى كه در زنجيره ارزش نفت داراى سهم مشار كت مشخصى باشد، بنيانخذارى كنند. البته

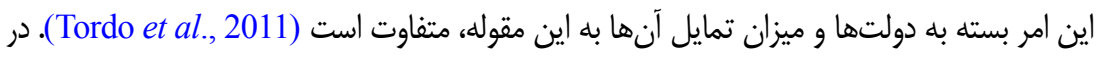

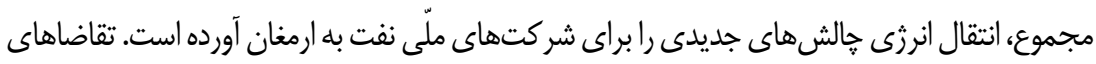

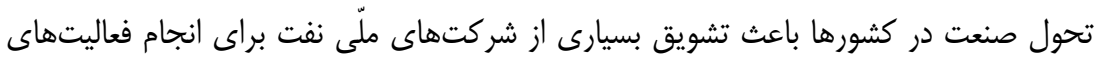

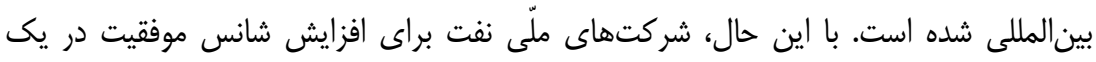

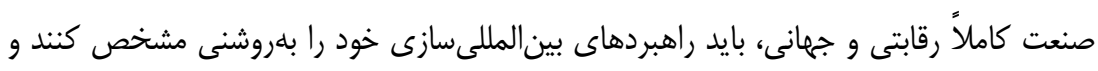
سازمانهاى خود را براى اين مسيرهاى رشد جديد آماده كنند (Guzman et al., 2019).

\section{دلايل اصلى براى بين المللى شدن شركت ملّى نفت ايران}

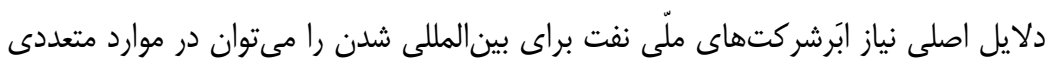

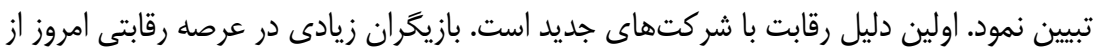

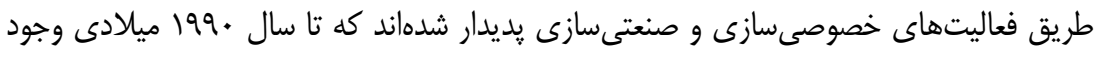

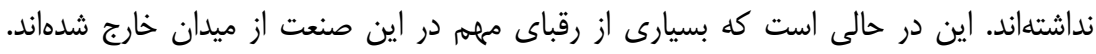

1. Statoil

2. Globally National Oil Companies (GNOCs) 
كسب بازارهاى مناسب يا حضور در كشورهاى جديد نيز از دلايل اصلى بينالمللى شدن است.

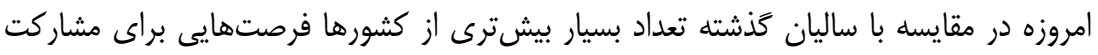

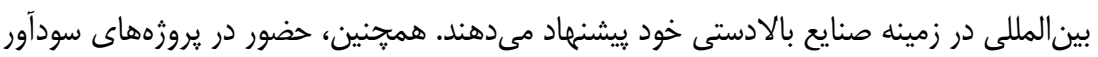

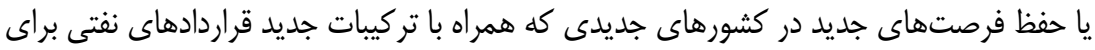

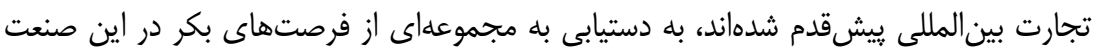

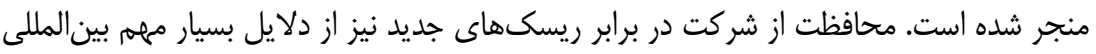

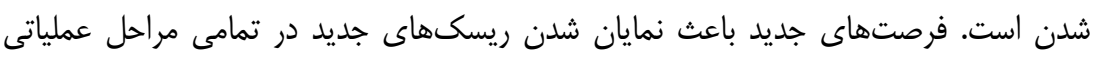

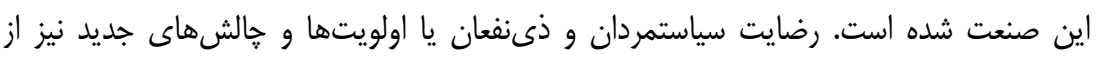

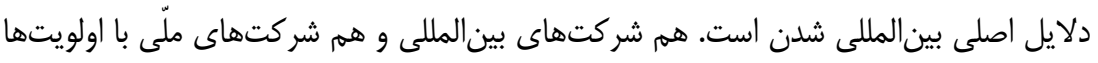

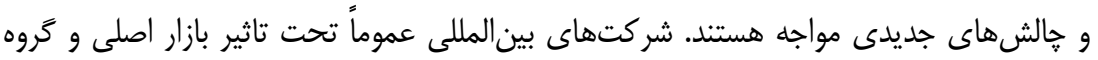

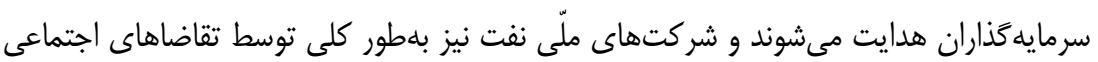

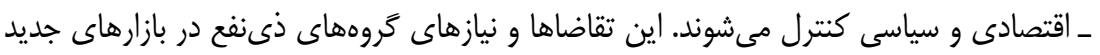

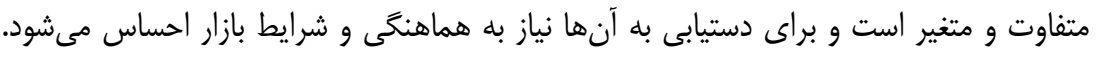

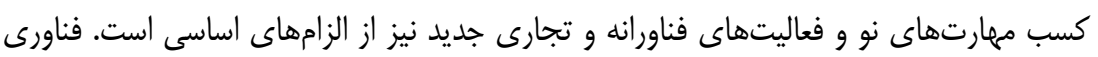

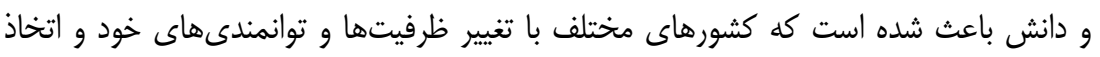

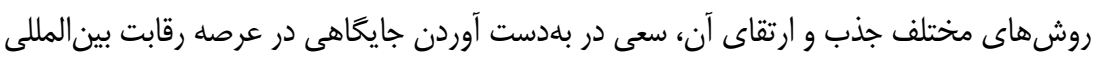

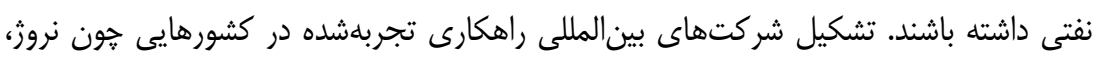

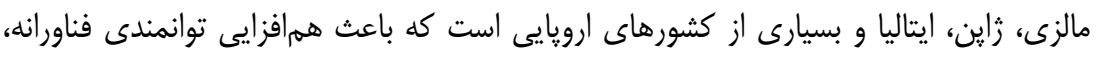

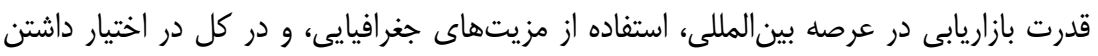
مزيتهاى نسبى شده است. بعترديد شركتهاى بينالمللى مهمترين نقش را در تبادل فناورى

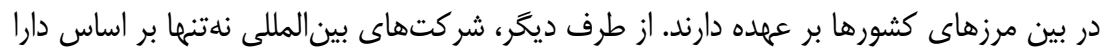

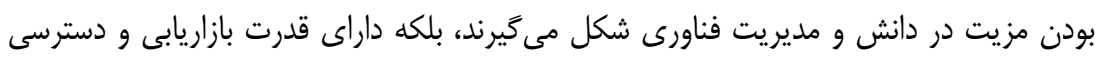

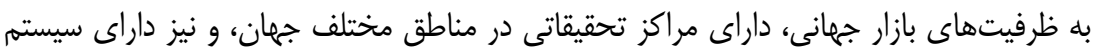

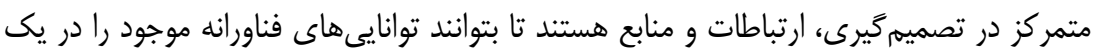
منطقه جغرافيايى براى حل مشكل يا استفاده در يك موقعيت ايجادشده در منطقه ديخر بكار كيرند

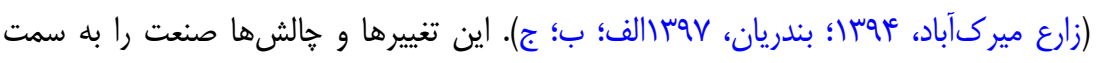

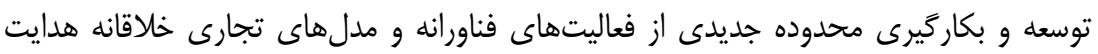

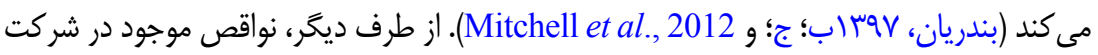


ملّّ نفت ايران نيز نياز به بينالمللى شدن را براى اين شركت تشديد مى كند.

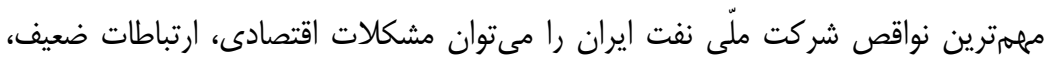

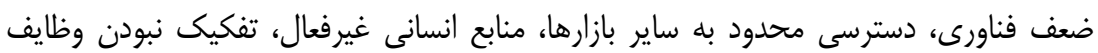

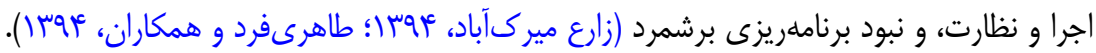

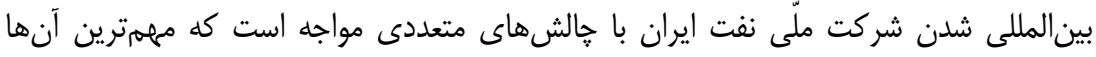
عبارتاند از ا. مشكلات سياسى: تعاملات سياسى در شكل دادن همكارىهاى بينالمللى نقش

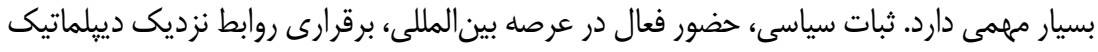
با كشورهاى شريك اقتصادى ازجمله ملزوماتى است كه به عنوان زيرساخت بايد مورد توجه قرار

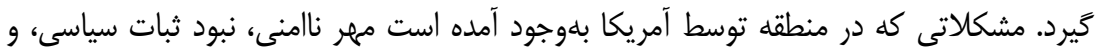

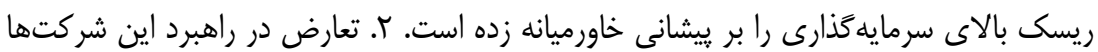

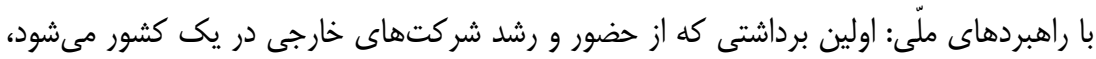

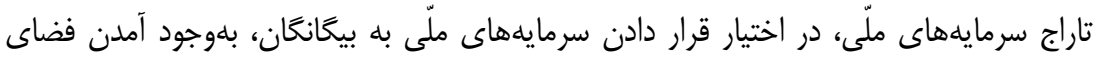

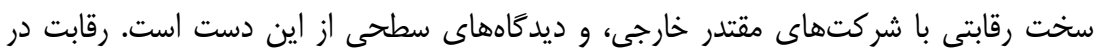

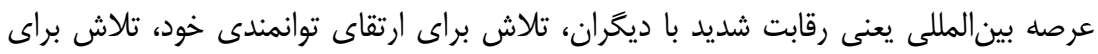

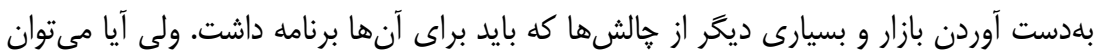

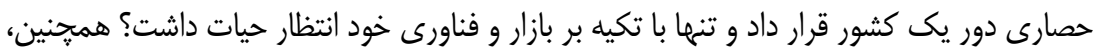
در حوزه حقوقى نبايد شك داشته باشيم كه ما تنها كشورى نيستيم كه دغدغهها و نكرا انىهايى درباره حضور شر كتهاى خارجى در صنعت نفت خود دارد، و به همين خاطر مطالعه هر خه دقيقتر

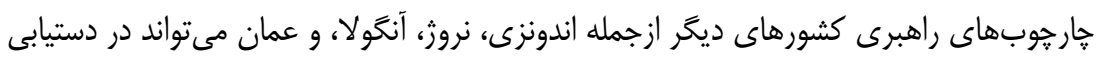

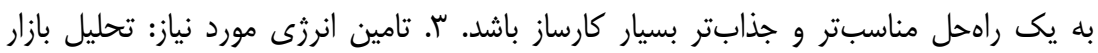

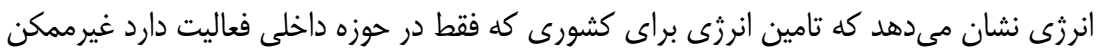

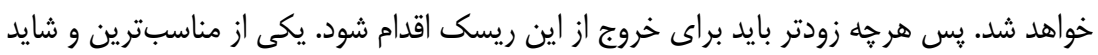

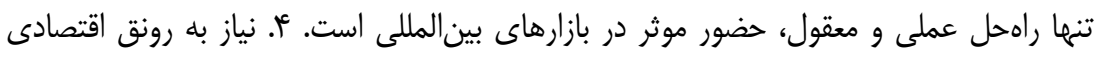

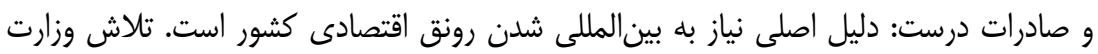

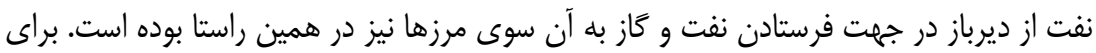

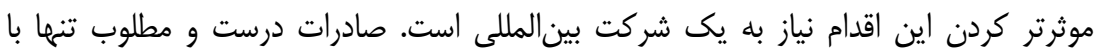

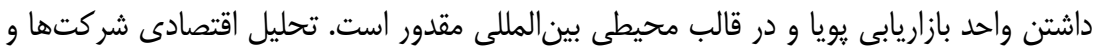

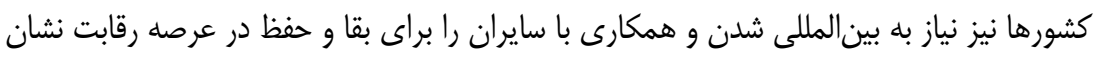


مىدهد؛ زيرا سود نفت و كاز در حال كاهش و سود خدمات جانبى اين صنعت در حال افزايش است

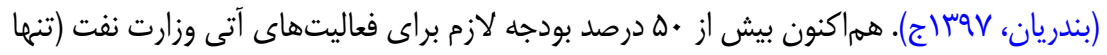

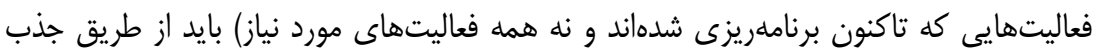
سرمايه خارجى تامين گردد، اين در حالى است كه جذب سرمايه در حالت بينالمللى بسيار آسانتر

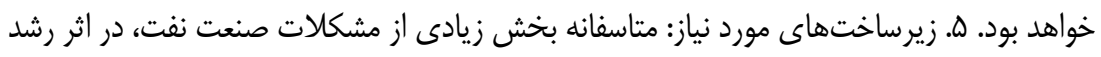
نامتوازن صنعت در كشور ماست. هيجكاه تصور نشده است كه رشد اقتصادى، توليد و ييشرفت،

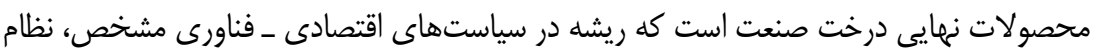

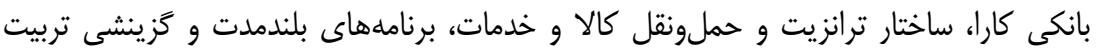

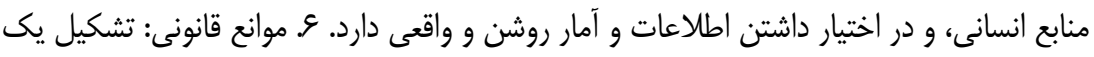

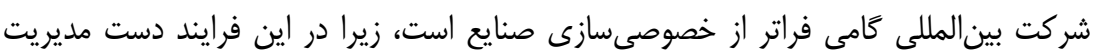
بينالملى به شركتها و نهادهايى مىرسد كه مدتهاست در تملك بىقيد و شرط دولت برات بودها

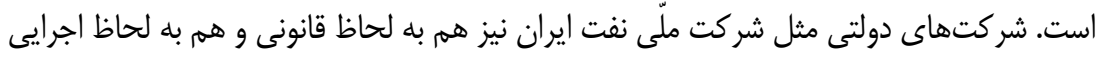
داراى موانع بسيارى است كه يكى از اولين اقدامهاى اساسى در جهت بينالمللى شدن، تغيير يا

تطبيق اين قوانين با شرايط بازار و دنياى صنعت نفت است (Kheir-andish et al., 2018).

\section{نقش راهبرى شر كتى در بين المللى شدن شر كتهاى ملّى نفت در جهان}

يافتهاى يزوهشهاى بيشين نشان مىدهد كه شركتهاى ملّى نفت كه در مسير

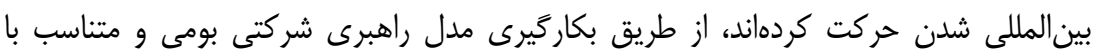
شرايط خاص خود، الزامها و زيرساختهاى لازم را براى فرايند بينالمللى شدن فرانس الهم نمودهاند (Kumar \& Reshma, 2018; Marcel, 2006; 2016; Guzman et al., 2019) نشان مىدهد كه در كشور روسيه بين هر دو متغير بينالمللى شدن و راهبرى شركتى همبستىى

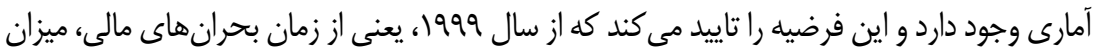

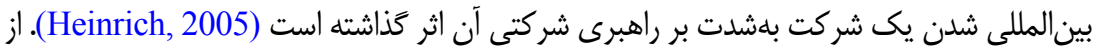
طرف ديخر در اوايل قرن بيستويكم، دنيا نظارهر شمار زيادى از رسوايىهاى مالى در شركتهايى

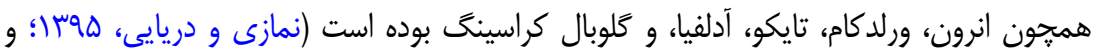

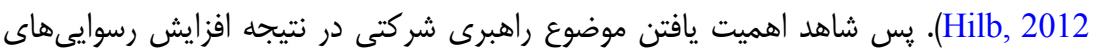

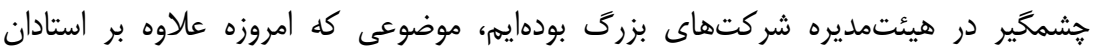
دانشخاهى، از مباحث جهانى مورد علاقه يزوهشكران است (هيلب، هوسا). تعريف جامعى كه از 
راهبرى شركتى در ايران بيان مىشود عبارت از قوانين، مقررات، ساختارها، فرايندها، فرهنگها،

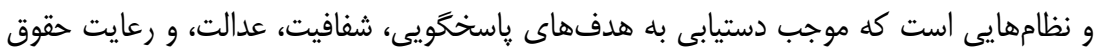

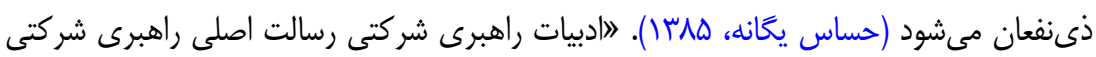
را در قالب دو هدف ايجاد ارزش و محافظت از ارزش طبقابندى نموده است. هدف ايجاد ارزش

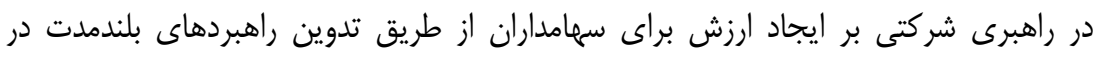

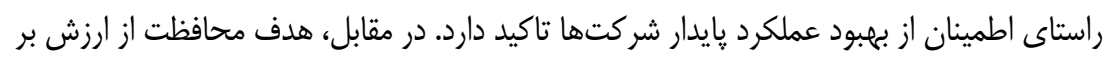

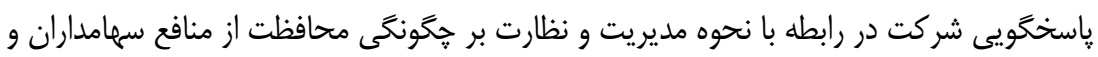

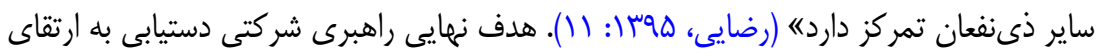
انصاف، شفافيت و ياسخكويى، و رعايت حقوق ذى نفعان در بنكاههاى اقتصادى است. عملكرد

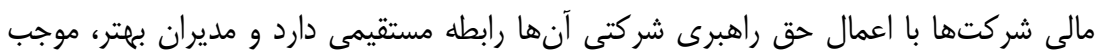
راهبرى موثرتر شركت مىشوند و به ذىنفعان خود توجه مى كنند و در نهايت بازده مالى بيشترى

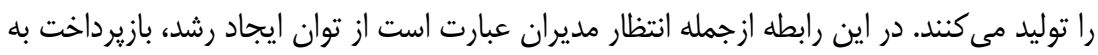

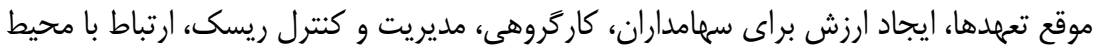

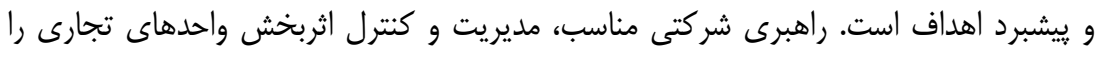

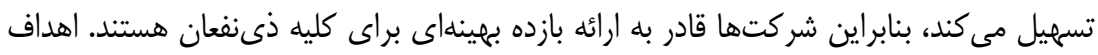

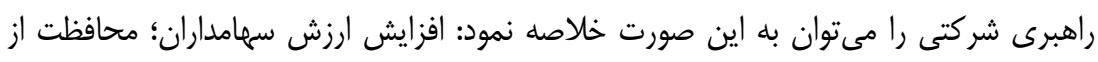

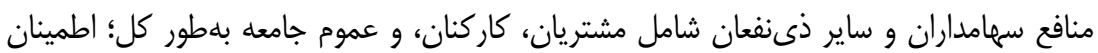

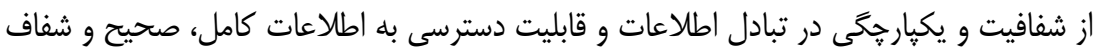

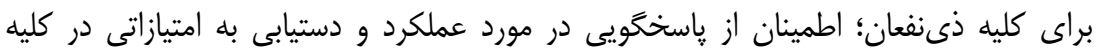

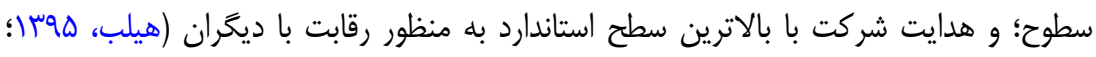

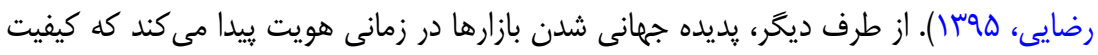

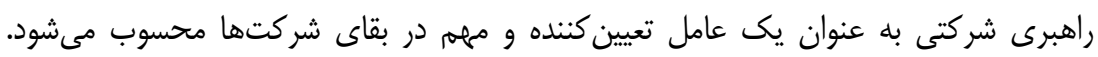

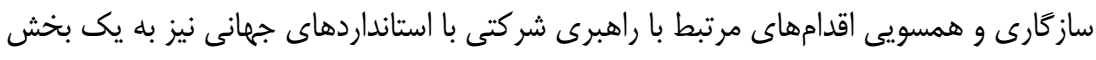

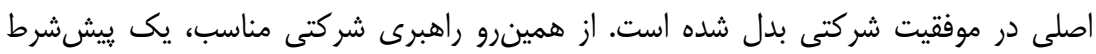

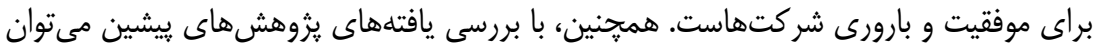

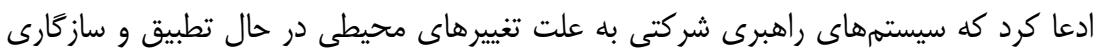
دائمى هستند (Marcel, 2006; Guzman et al., 2019). بر اساس الزامهاى خاص هر كشور،

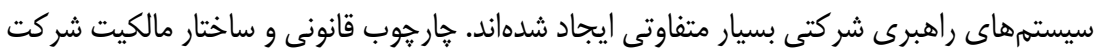


مهمترين عوامل در تعيين سيستم راهبرى شركتى يك كشور هستند و ساير عوامل جانبى نيز

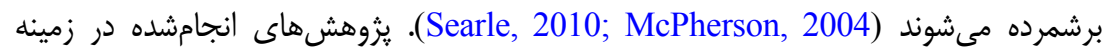
راهبرى شركتى بيشتر بر اين موضوع تاكيد دارند كه يك الكوى واحد و مشابه براى كشورهاى برد

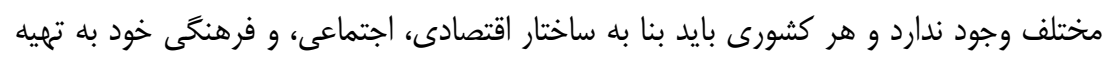

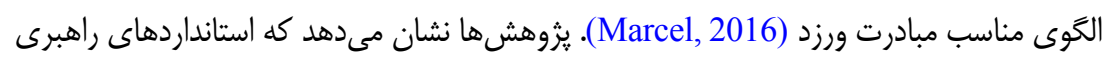
سازمانى شركتهاى ملّى به نسبت شركتهاى بينالمللى بسيار ضعيف است. اين نتيجه مى متواند

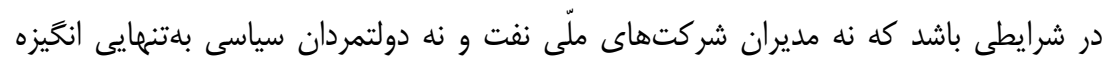

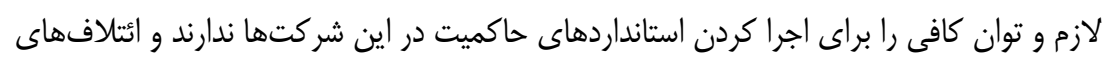

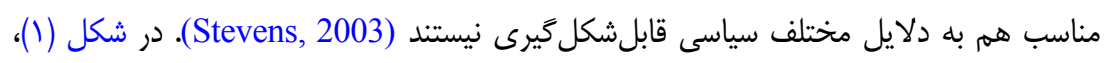

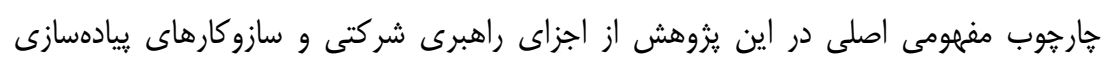
راهبرى شركتى نمايش داده شده است.

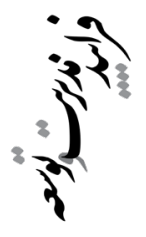




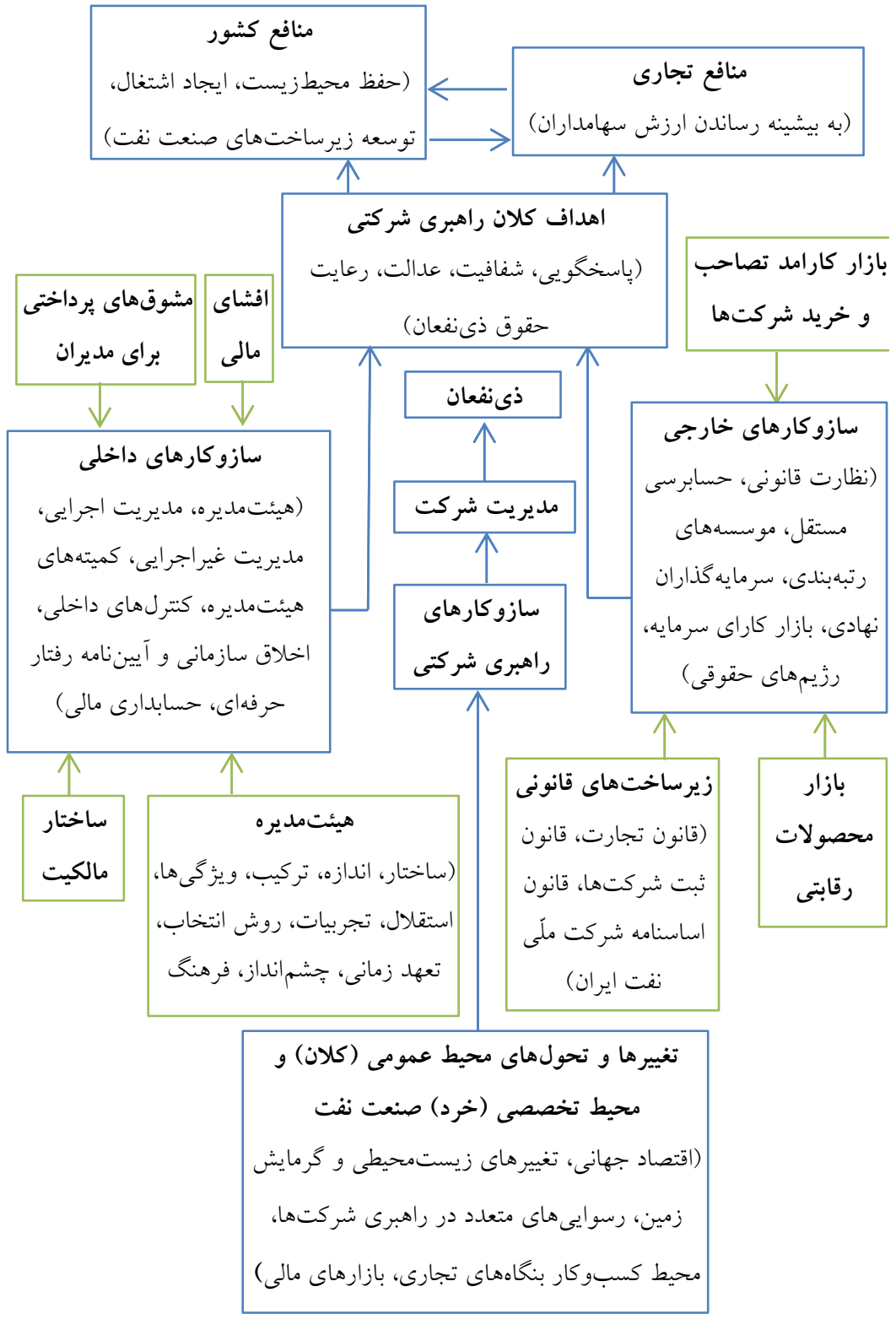

شكل 1: جارجوب مفهومى اصلى يزوهش از اجزاى راهبرى شر كتى و سازوكارهاى پيادهسازى راهبرى شر كتى أز 


\section{روششنى بزوهش}

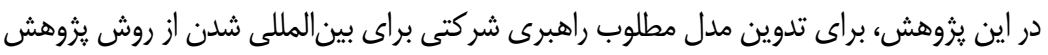

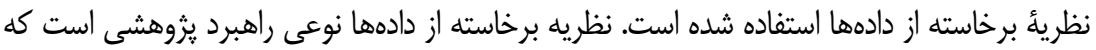
در بي تدوين نظريه است و ريشه در دادههايى مفهومى دارد كه به صورت نظامند كَّردآورى و تحليل شدهاند. اين راهبرد با استفاده از رويكرد استقرايى سعى در مفهومسازى دادهها (كردآورى و تحليل دادهها

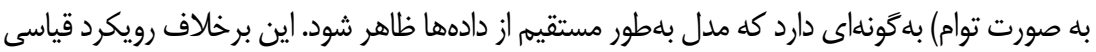

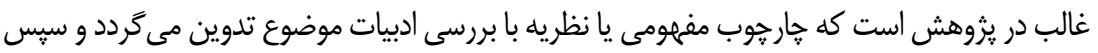

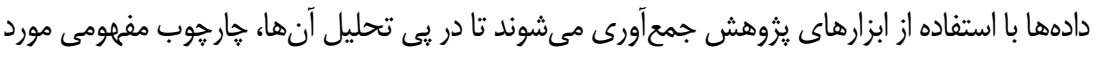

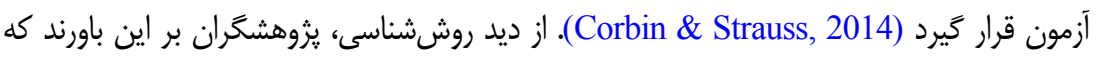
روش يزوهش كيفى بينش عميقترى در قبال يديدههاى فرايندى فراهم مىسازد. يكى از مشخصههاى

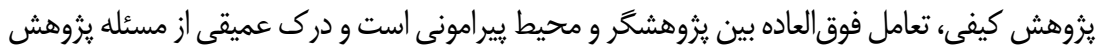

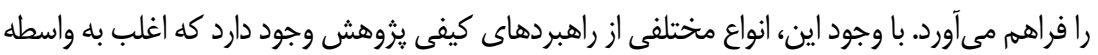
تفاوت در شيوه جمع آورى و تحليل دادهها، تفاوتهايى با يكديكر دارند. يكى از انواع مختلف اين راهبردها روش نظريه برخاسته از دادهاست. هدف نهايى نظريه برخاسته از دادها، ارائه تبيينهاى

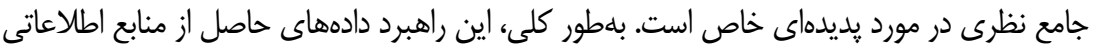

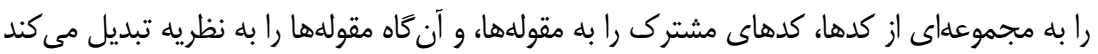
(Charmaz, 2006; Corbin \& Strauss, 2014) نظريهيردازى در خصوص حار یوب مطلوب راهبرى شركتى در راستاى بين المللى شدن شركت ملّى نفت ايران هستيه، از اين روش يزوهش استفاده مى شود. همجنين، براى تعريف عملياتى از بين المللىسازى درى

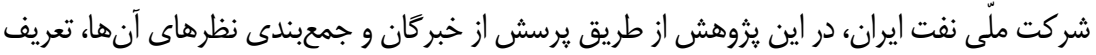

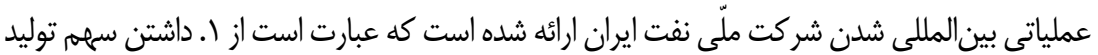

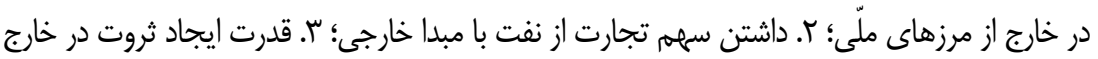

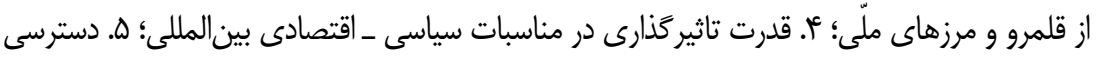

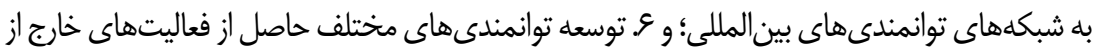
مرزهاى ملّى و انتقال دانش فنى و فناوىى. جامعه آمارى يزوهش حاضر در بخش كيفى و براى دستيابى بله مدل مفهومى أولى اوليه مطلوب

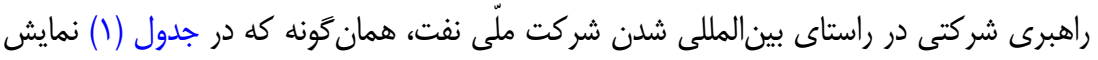


داده مىشود، شامل اعضاى هيئت علمى دانشكاهها، كارشناسان اقتصاد انرزى و حقوق نفت، و مديران اجر ايى با سابقه فعال در صنعت نفت و صاحبنظر در زمينه مسائل راهبرى و حقوقى نفت مى شوند.

جدول ا: آمارهاى جمعيتشناختى خبر كان مورد مصاحبه در فرايند يزوهش

\begin{tabular}{|c|c|c|c|c|}
\hline (سال) & 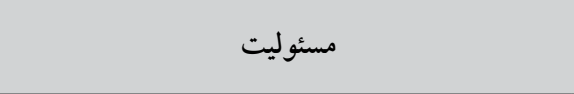 & تخصص & (سال) & خبره \\
\hline rV & مدير عامل و عضو هيئتمديره شركت ملّى نفت ايران & مديريت اكتشاف & aY & 1 \\
\hline r^ & عضو هيئتعلمى دانشخاه علامه طباطبايى & حقوق بين الملل & $\Delta \wedge$ & r \\
\hline ir & عضو هيئت علمى / اجرايى - يثزوهشخاه وزارت نفت & مديريت صنعتى & ra & r \\
\hline r & عضو هيئت علمى دانشخاه & مديريت منابع انسانى & iQ & r \\
\hline r. & عضو هيئت علمى دانشخاه علامه طباطبيى & حقوق خصوصى & $\Delta \wedge$ & $\Delta$ \\
\hline$\mu \cdot$ & عضو هيئتعلمى / اجرايى & 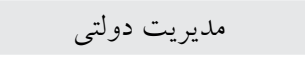 & ar & 9 \\
\hline rA & عضو هيئتعلمى / اجر ايى - عضو هيئتمديره & 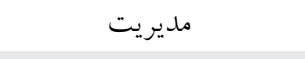 & \&V & V \\
\hline r & عضو هيئتعلمى دانشكاه تهران & 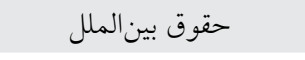 & $9 \Lambda$ & $\wedge$ \\
\hline$r \cdot$ & عضو هيئتعلمى دانشكاه تهر ان & حقوق خصوصى & Gr & 9 \\
\hline 10 & كارشناس ارشد حقوقى شركت ملٌى نفت ايران & 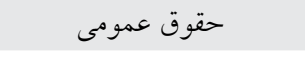 & Q. & $1 \cdot$ \\
\hline $1 \wedge$ & كارشناس ارشد حقوقى شركت ملّى نفت ايران & 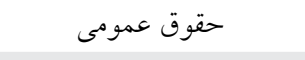 & $\Delta Q$ & 11 \\
\hline 1. & عضو هيئتعلمى دانشكاه تهر ان & 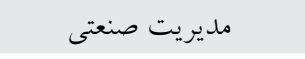 & Q. & ir \\
\hline r. & عضو هيئتمديره شركتى خصوصى نفتى & مديريت اجرايى & $\Delta \Delta$ & ir \\
\hline TQ & عضو هيئتمديره شركتى خصوصى نفتى & 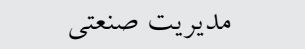 & $\Delta \wedge$ & 14 \\
\hline r. & عضو هيئتعلمى دانشكاه تهران & مديريت بازر كانى، راهبردى & Or & 10 \\
\hline
\end{tabular}

\section{جمع آورى دادههاى بزوهش}

ابزار اصلى مورد استفاده براى تدوين خار خوب مفهومى در اين يزوهش، مصاحبه نيمهساختاريافته است.

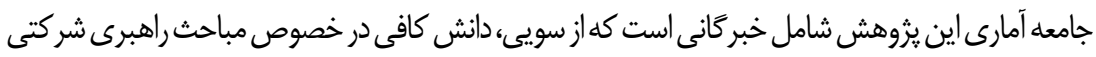

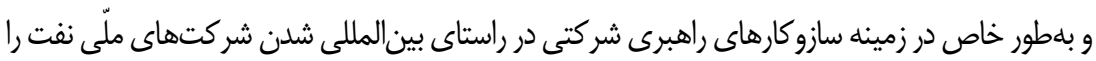

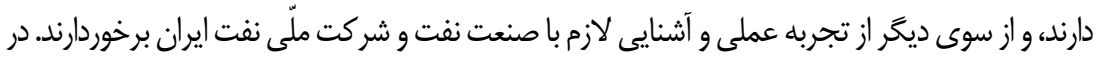

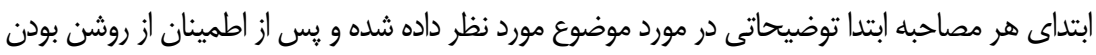

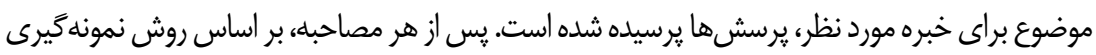


نظرى كلوله برفى، از مصاحبهشونده خواسته مى شد كه افرادى را كه از نظر آنها اشراف كامل به موضوع

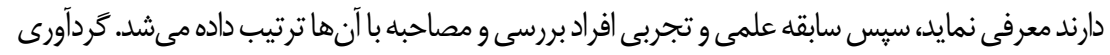

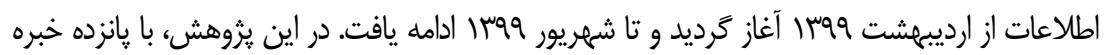
مصاحبه نيمهساختاريافته انجام شد كه از مصاحبه دهم به بعد، تكرار در اطلاعات مشاهده كَرديد (الشباع

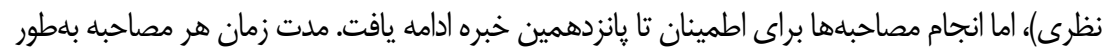

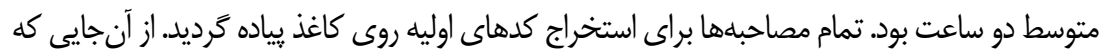
در اين يزوهش براى تجزيهوتحليل دادههاى حاصل از مصاحبه از روش نظريه برخاسته از دادهها استفاده شده است، ابتدا متن هر مصاحبه بررسى شده و با توجه به هر جمله اساسى درون متن، نكتههاى كليدى در

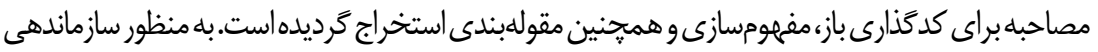

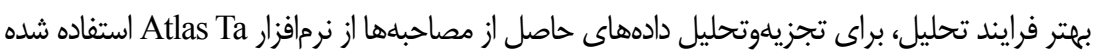
است. جدول (Y)، يرسشهاى اصلى و فرعى يرسيدهشده از مصاحبهشوندًان را زاز ارش مى كند.

جدول r: راهنماى مصاحبه نيمهساختاريافته

\begin{tabular}{|c|c|}
\hline & \\
\hline 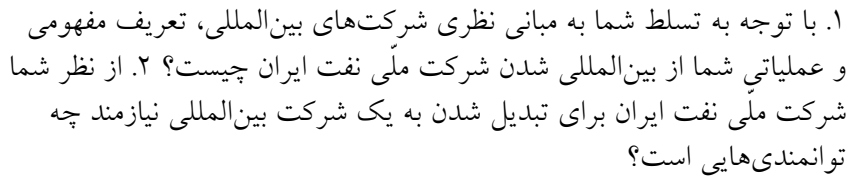 & 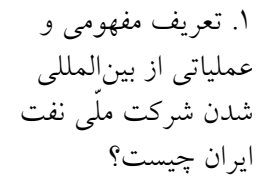 \\
\hline 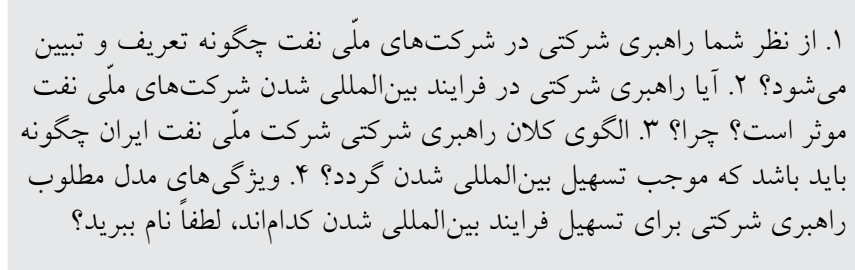 & 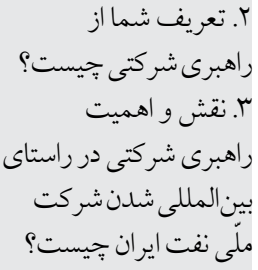 \\
\hline 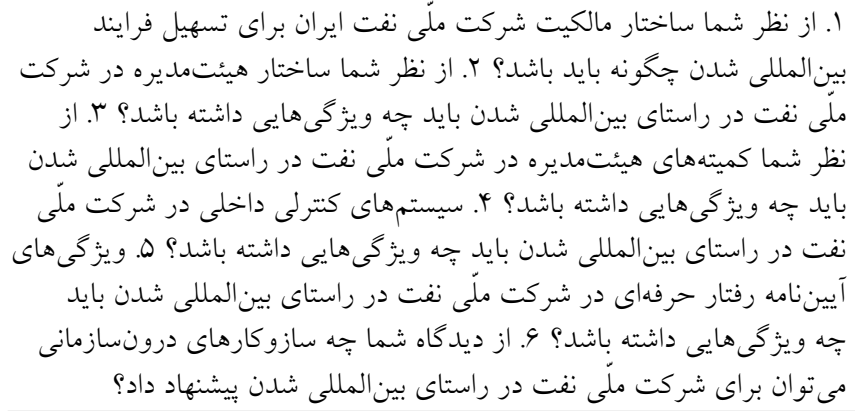 & در شفت ايران \\
\hline
\end{tabular}




\begin{tabular}{|c|c|}
\hline ششهاى فرعى & ملى \\
\hline 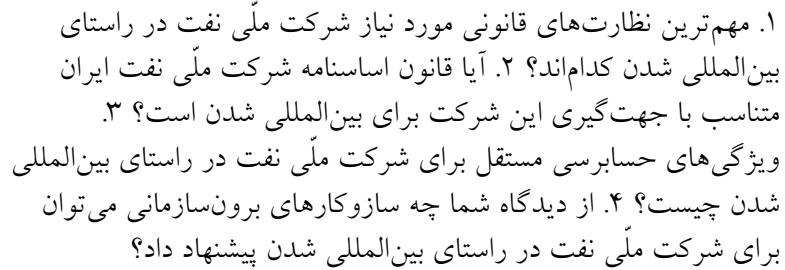 & 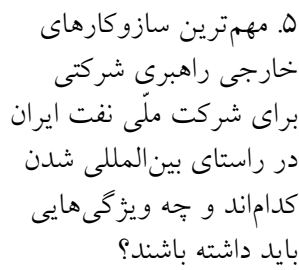 \\
\hline
\end{tabular}

\section{نظمدهى و تحليل دادهها}

كدگذارى اساس فرايند تحليلى در نظريهيردازى دادهبنياد است. در نظريهيردازى دادهبنياد

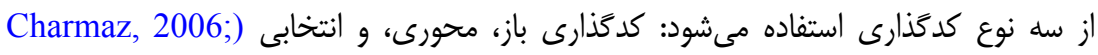

(Corbin \& Strauss, 2014

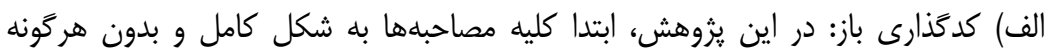

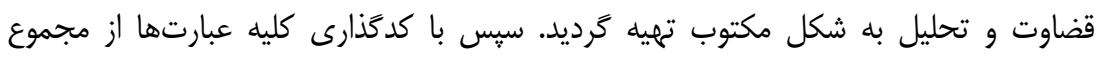

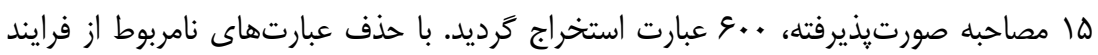

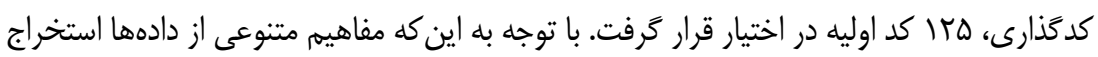

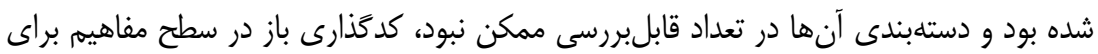

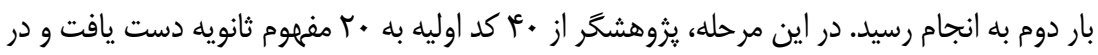

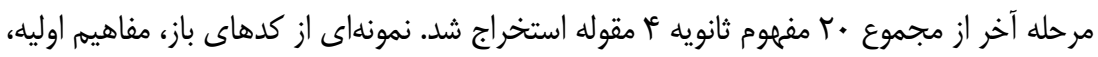

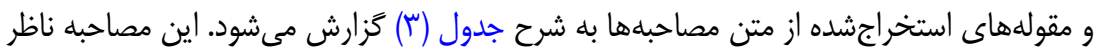

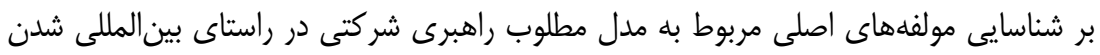

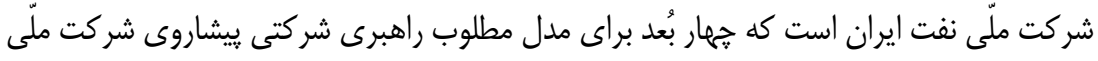

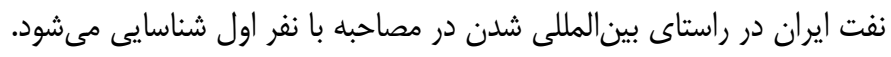




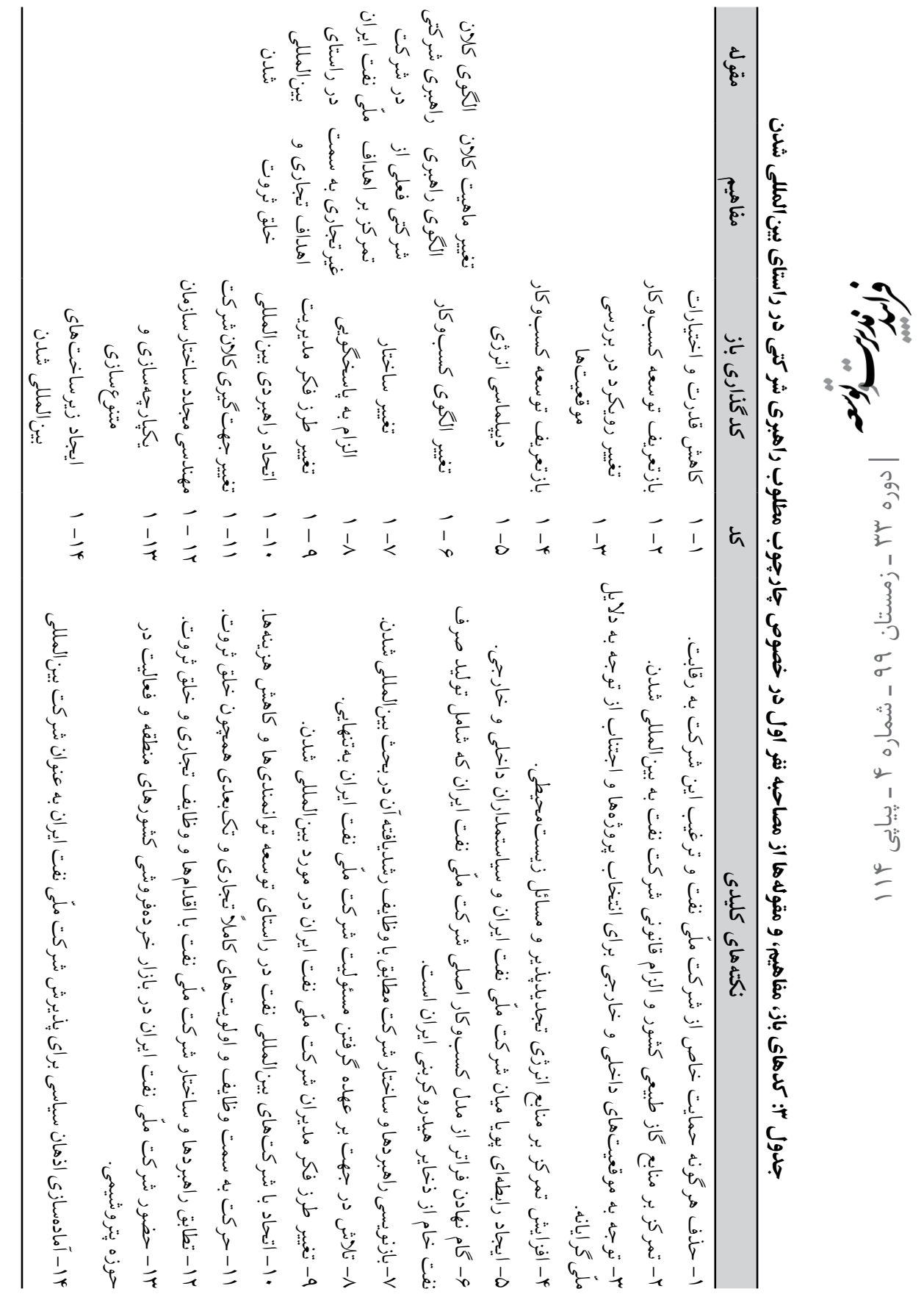



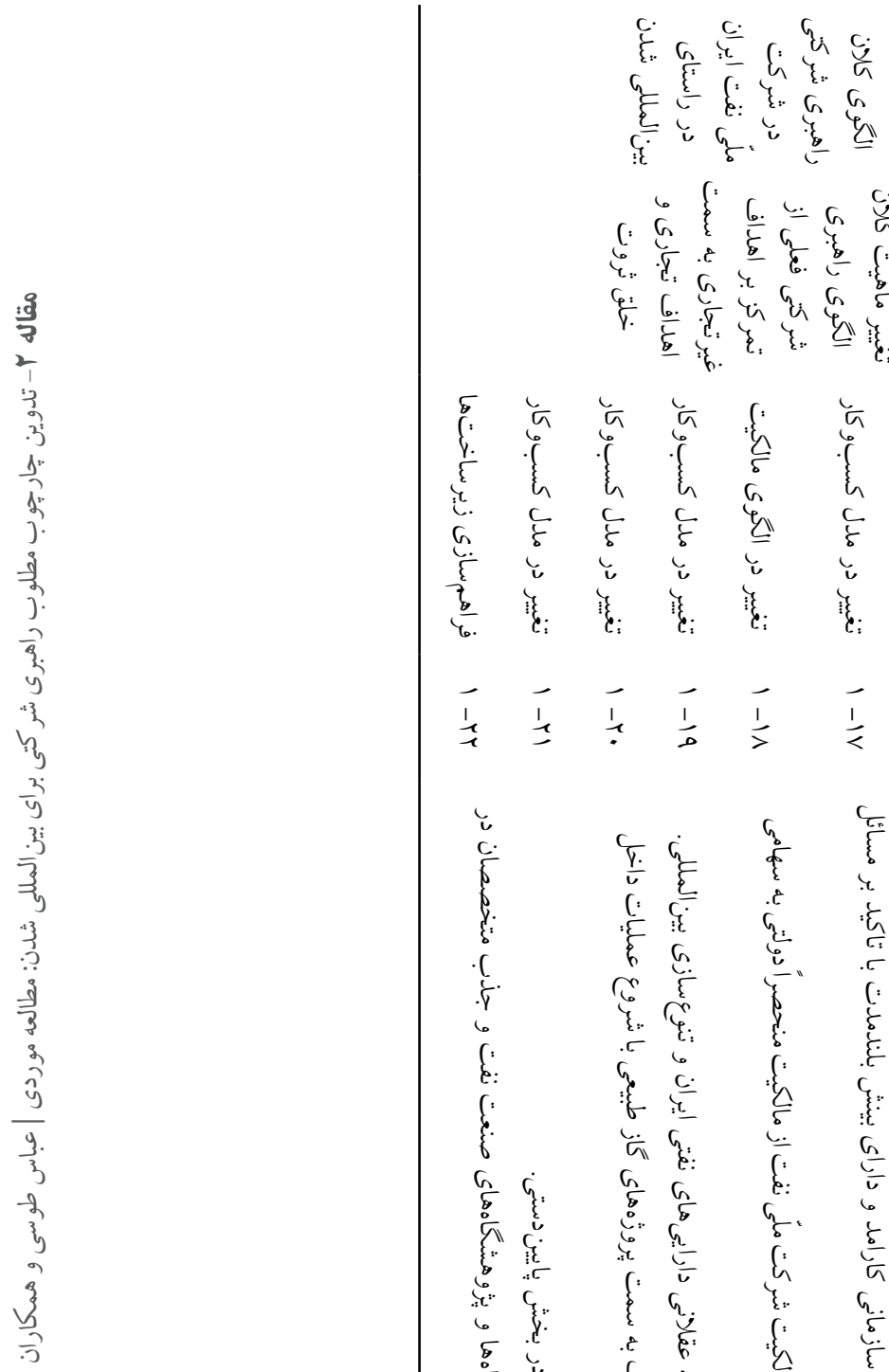

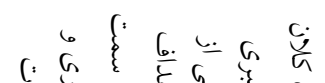

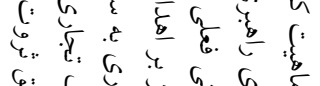

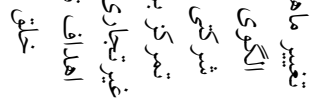

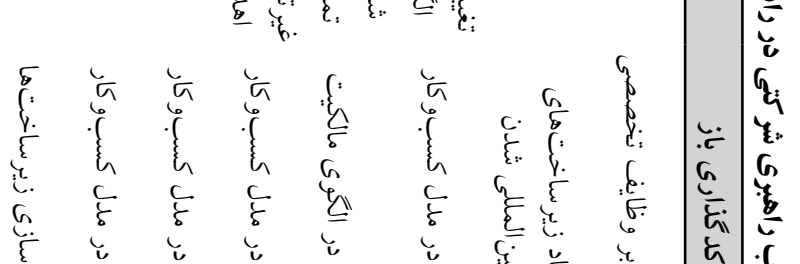

है है है

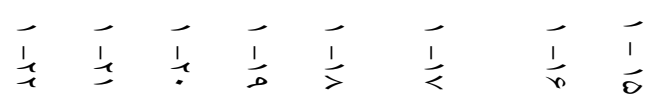

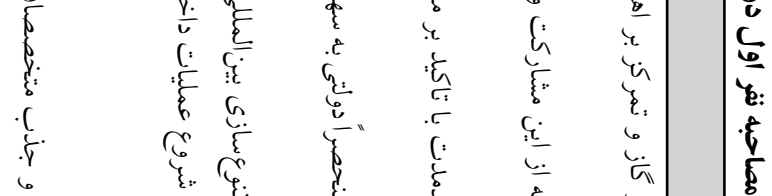

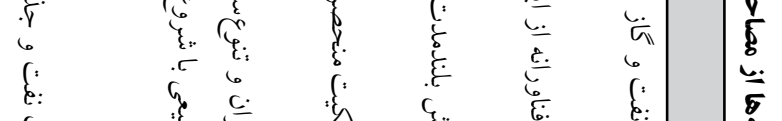

धी दो है दे है है है

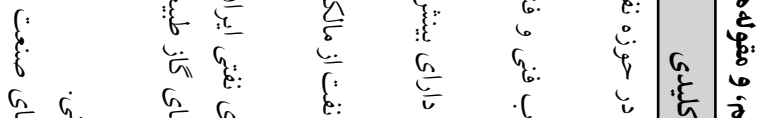

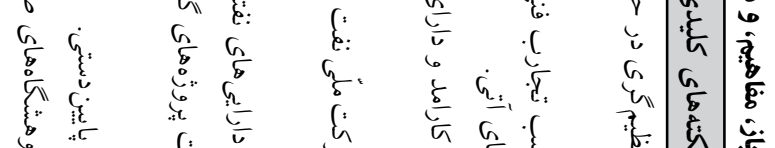

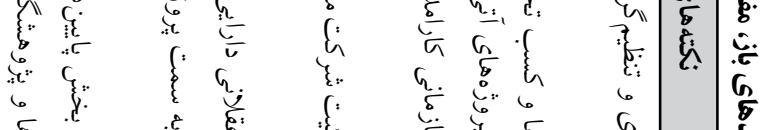

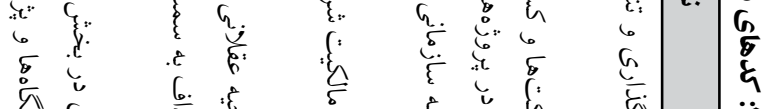

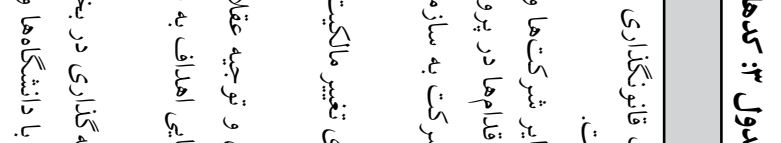

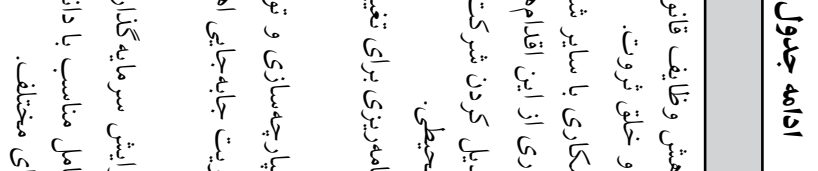

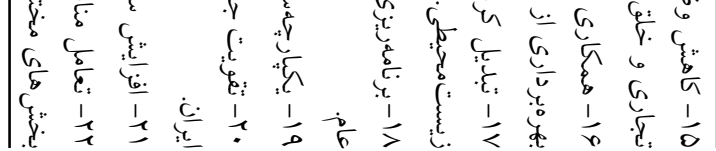




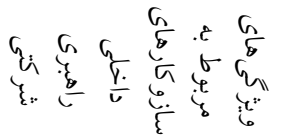

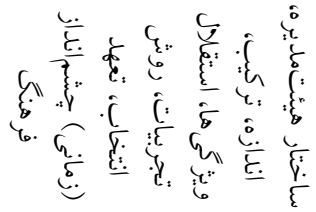

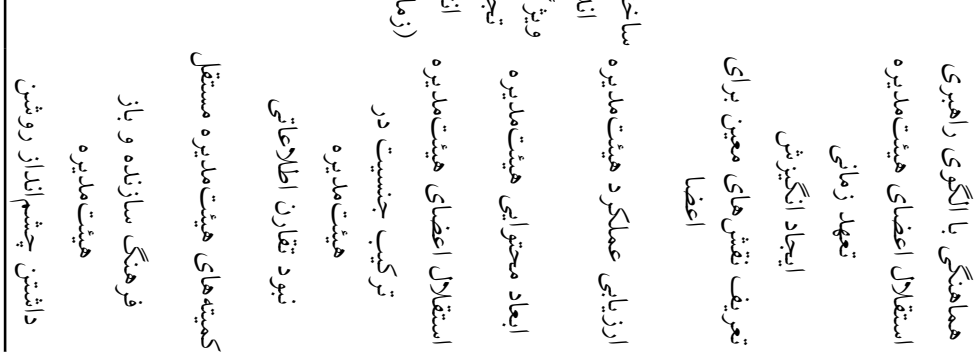

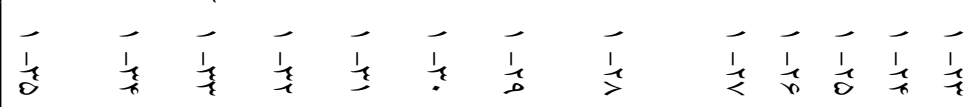

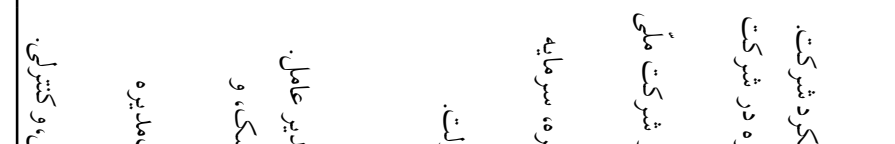

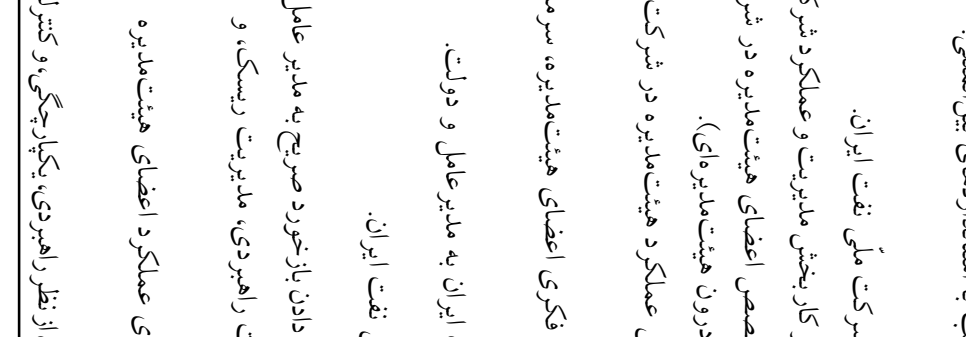
है

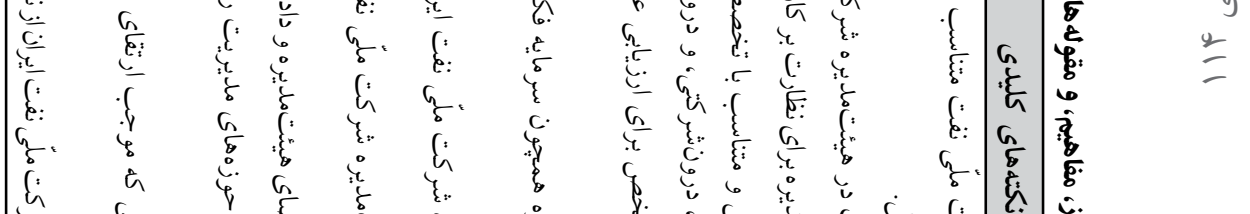
b cas

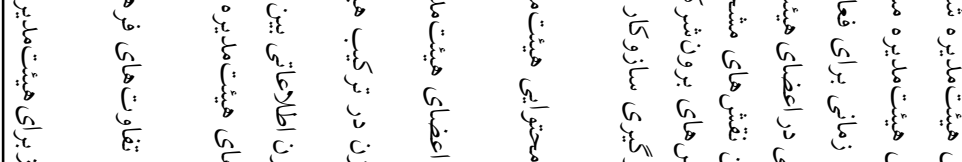
t

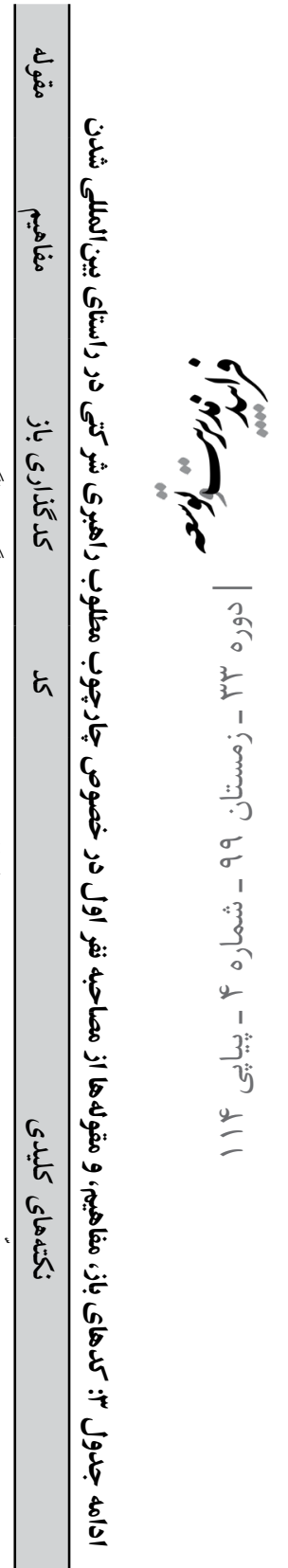

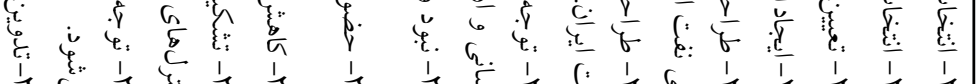

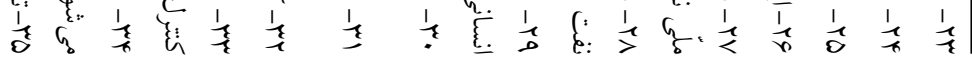




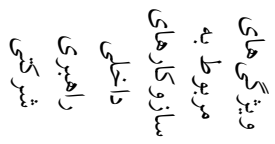

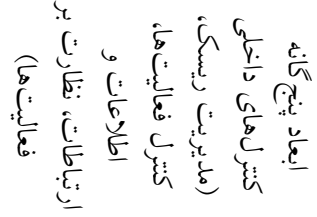

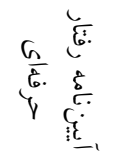

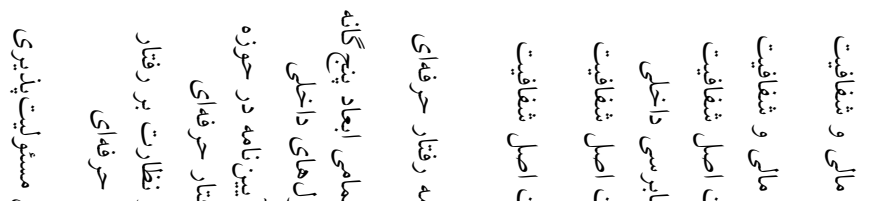
它

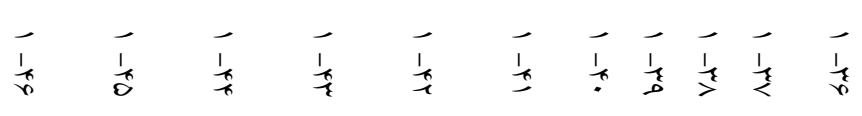

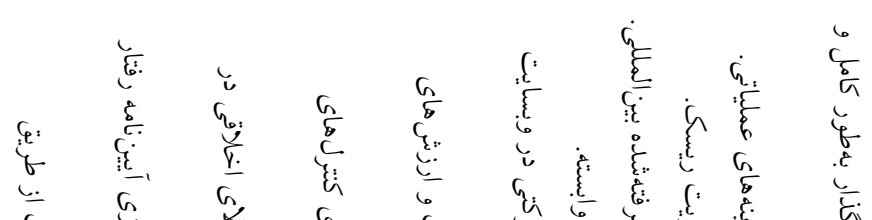

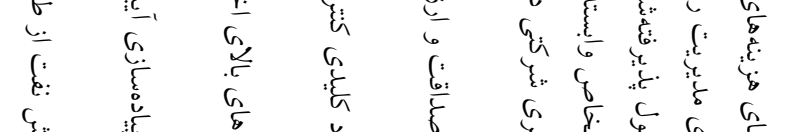

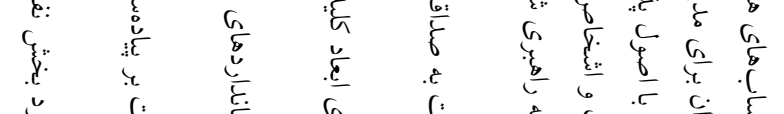
है है दू

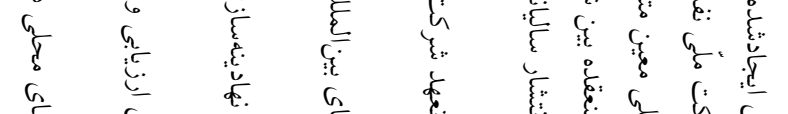

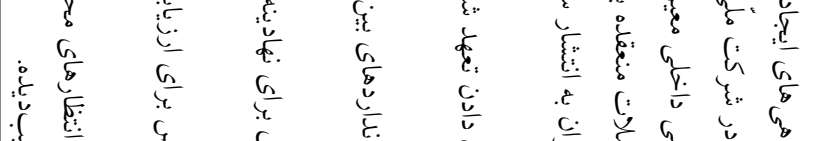

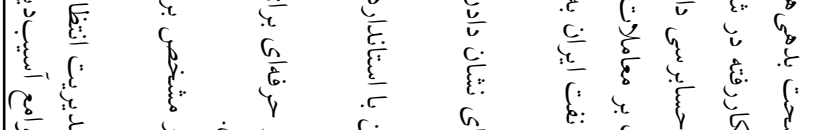

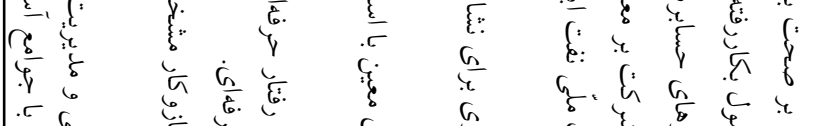

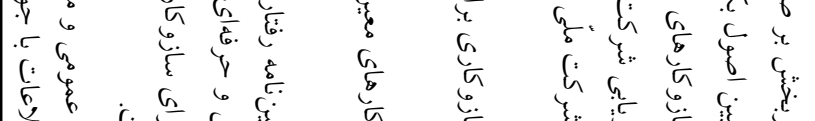
है

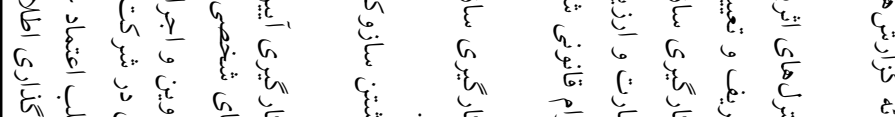

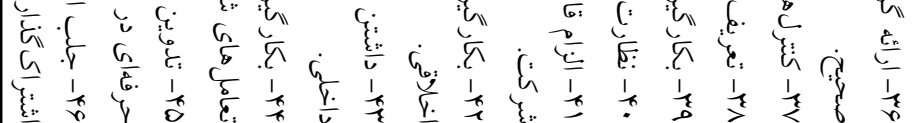

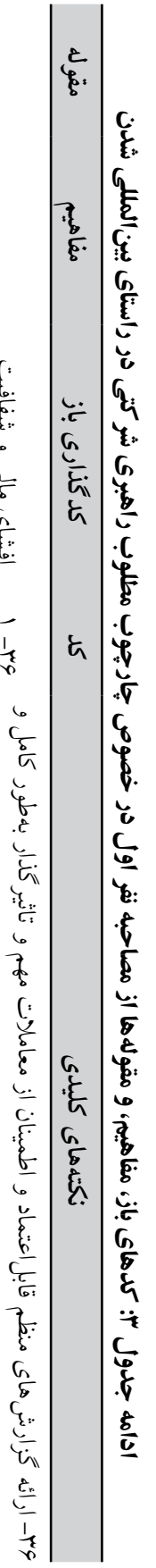




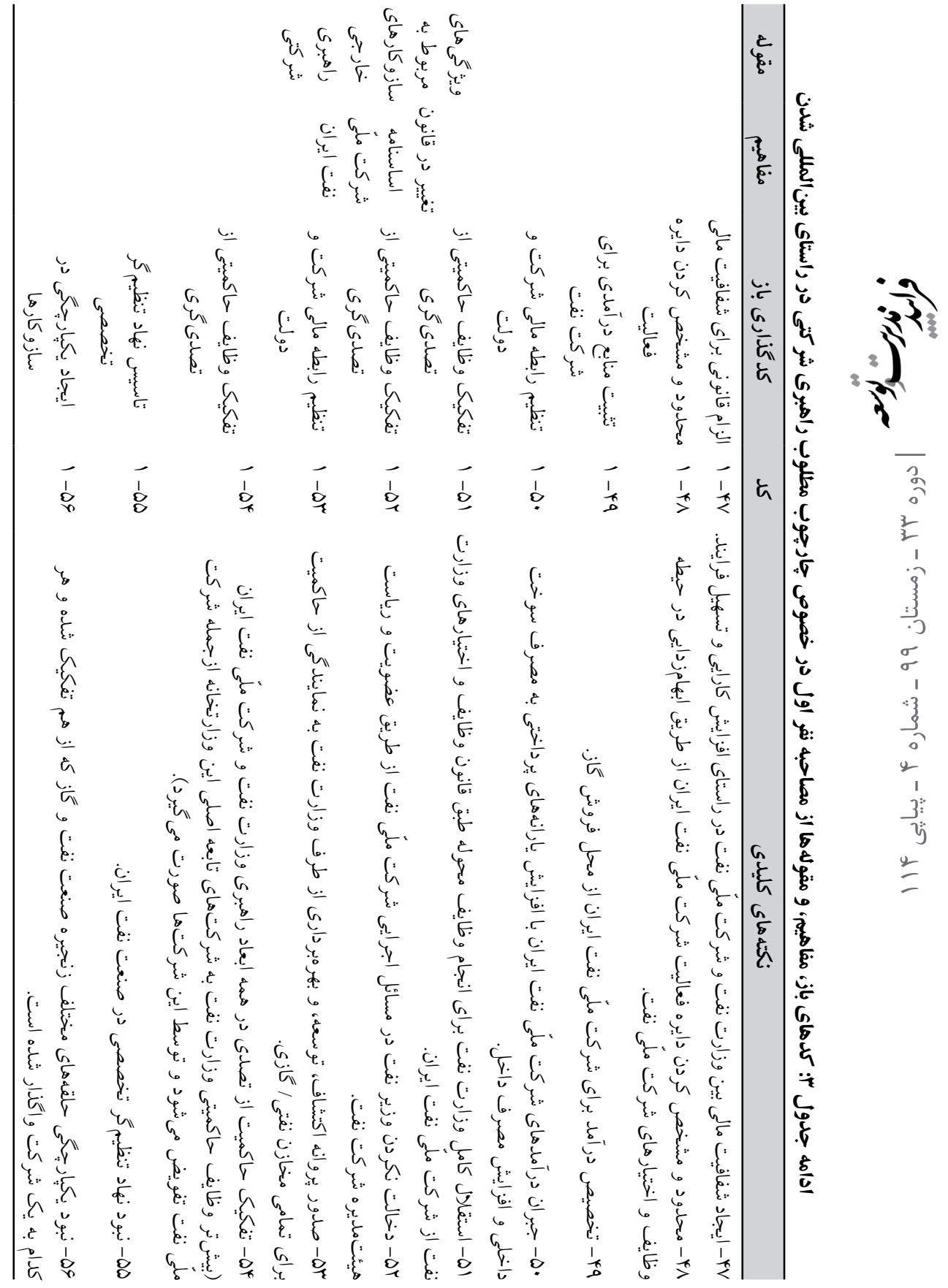




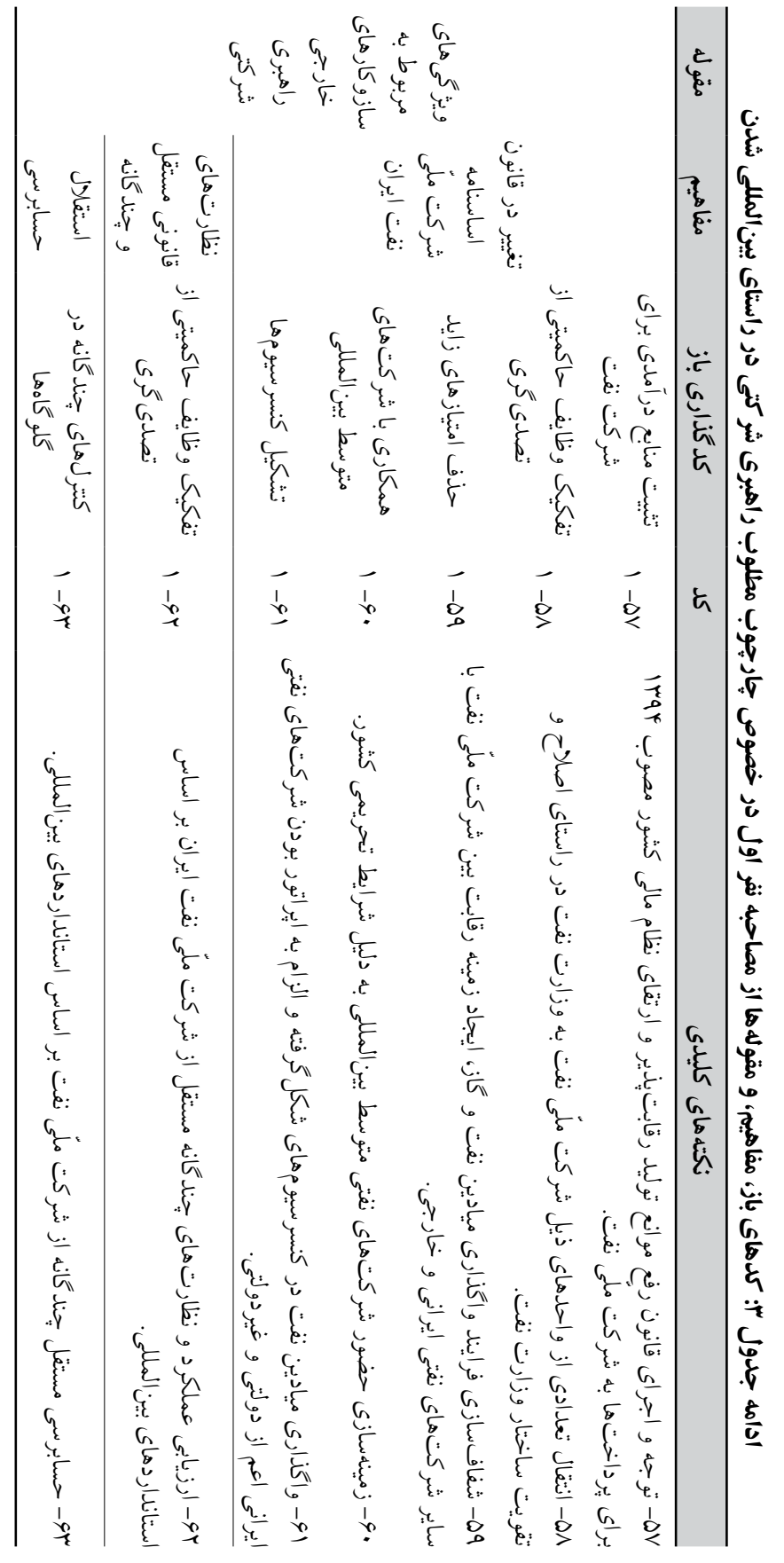


ب) كدكذارى محورى: در اين يُوهش از الكوواره كدگذارى نيمهساختاريافته كوربين و اشتراوس

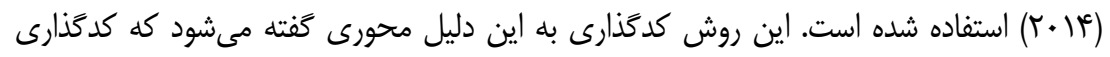

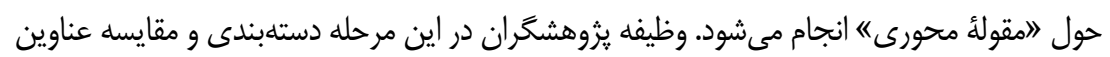

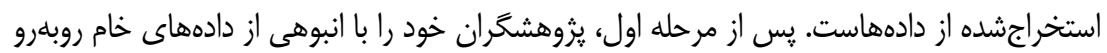

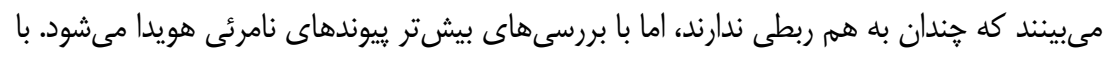

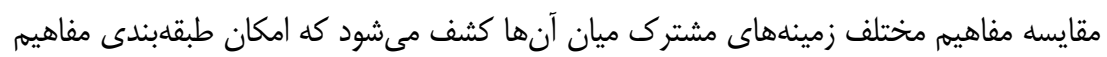

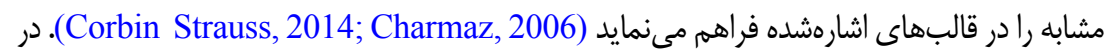

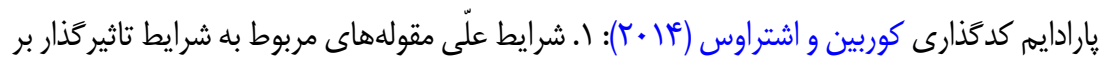

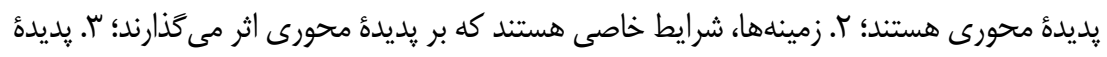

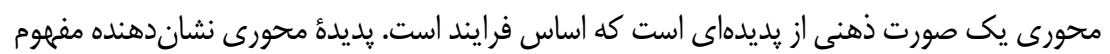

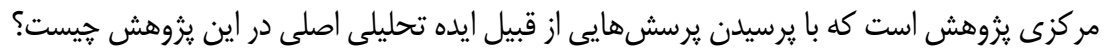

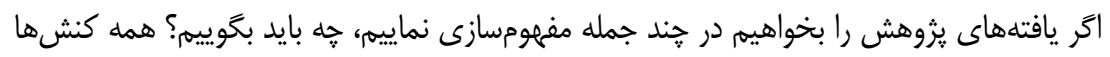

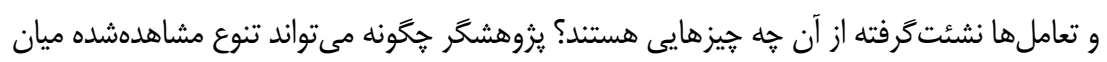

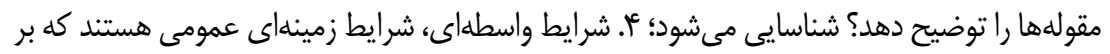

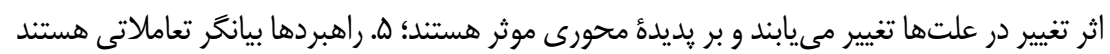
كه از يديده محورى منتج مىشوند. در حقيقت، يزوهشكران بايد مشخص نمايند كه با تغيير شر ايط

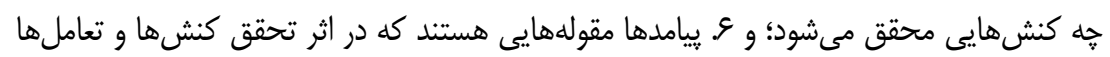

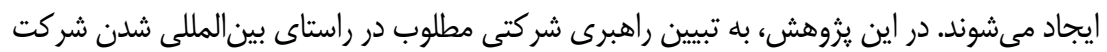

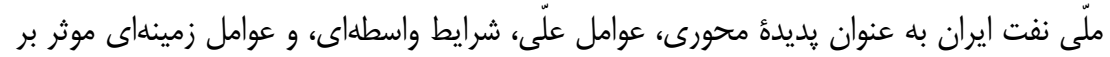

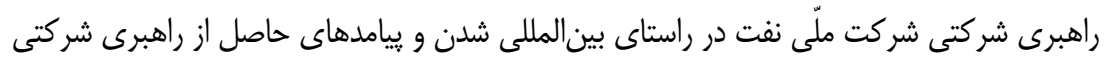
مطلوب يرداخته مى شود.

\section{ارزيابى اتكايذيرى يافتهها}

طراحى روششناسى و طرح يزوهش بلهحوى است كه بتواند دادها و تفسيرهايى مناسب

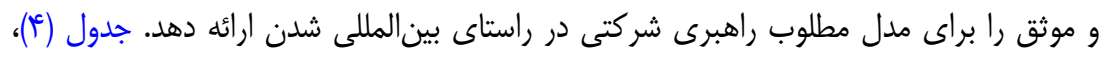
خلاصهاى از معيارهاى سنجش كفايت فرايند يزوهش و كيفيت دادهها و تفسيرها را نشان مىدهدا. 


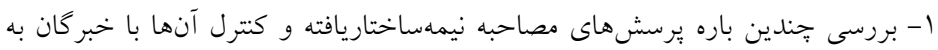

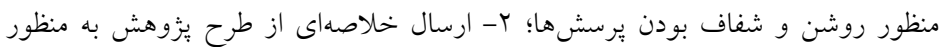

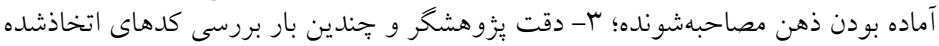

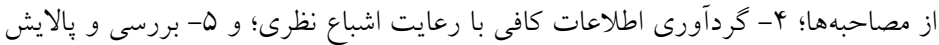

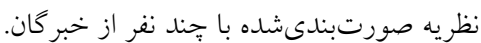

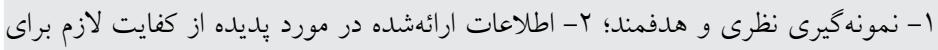

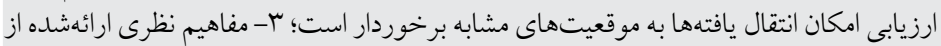

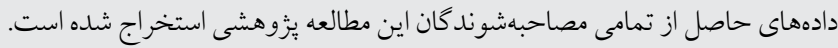

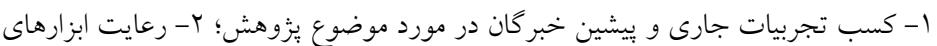

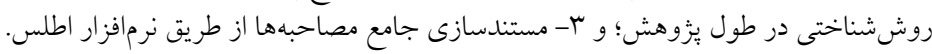

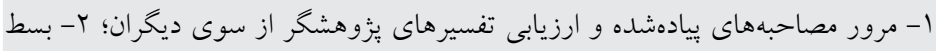

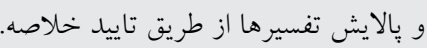

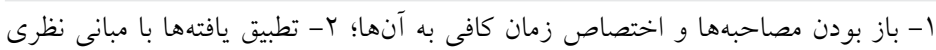

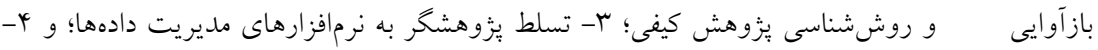

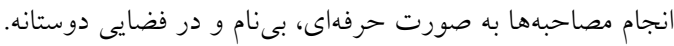

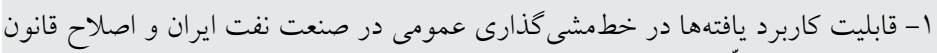

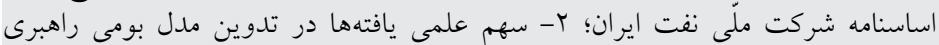

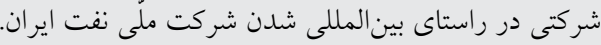

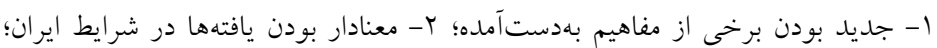

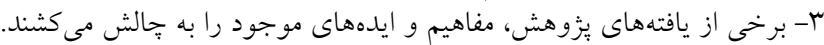
اصيل بودن

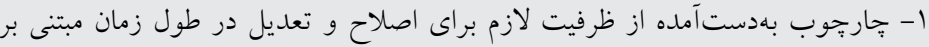

\section{يافتههاى ثزوهش}

در مصاحبههاى انجامشده با خبركان سعى مىشود كه مدل مطلوب راهبرى شركتى و

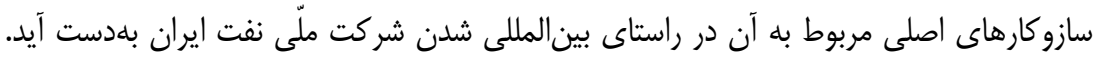
در مصاحبهها به بررسى تعاريف مفهومى و عملياتى از بينالمللى شدن شركت ملّى نفت ايران و مدل مطلوب راهبرى شركتى در راستاى بينالمللى شدن يرداخته مىشود و نتايج حاصل از

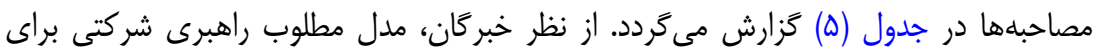

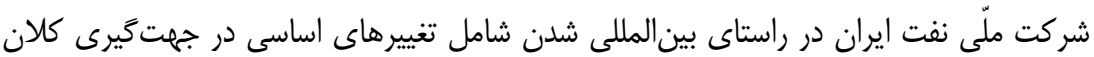


راهبرى شركتى در راستاى ايجاد توازن ميان اهداف تجارى و غيرتجارى به منظور ايجاد بهترين

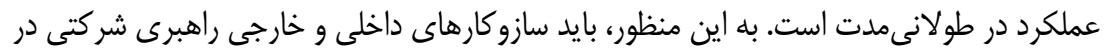

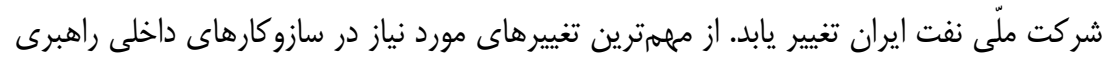

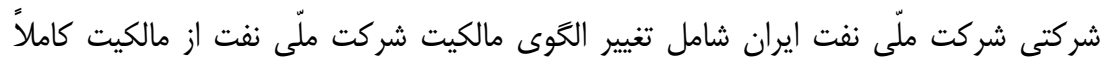

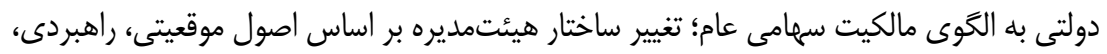

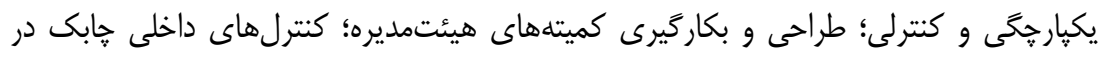

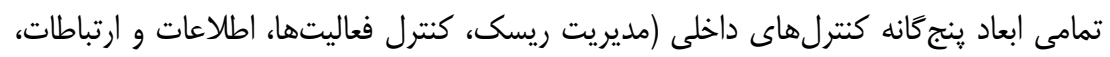

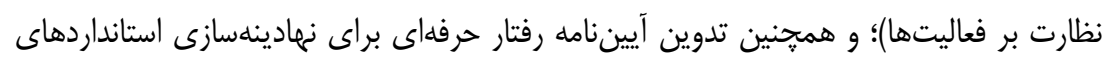

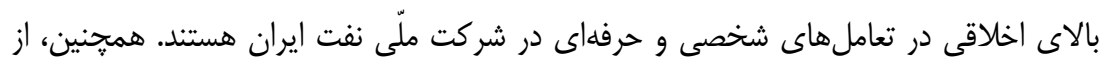

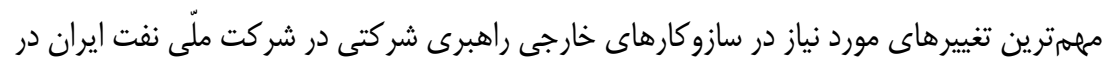

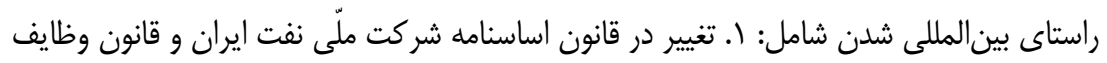

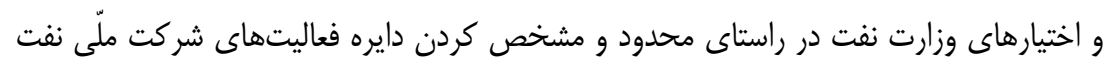

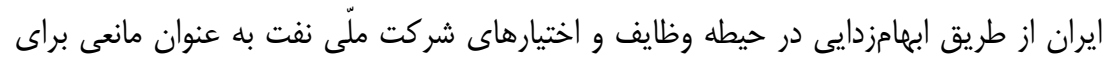

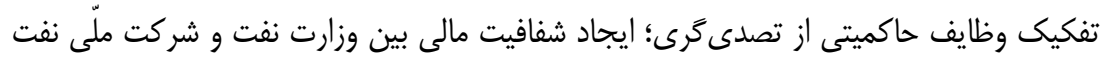

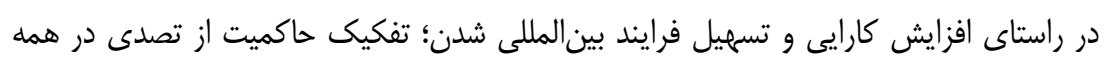

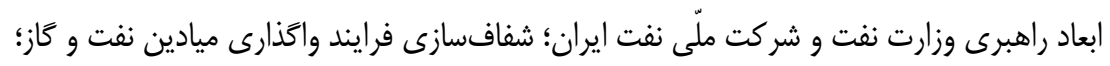

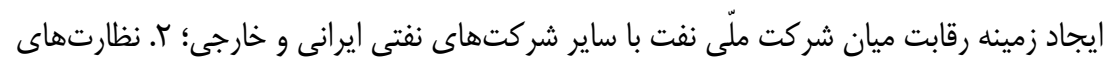

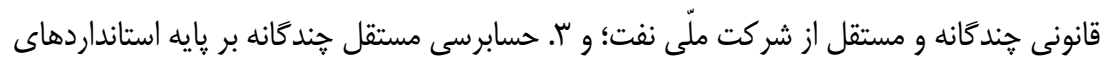

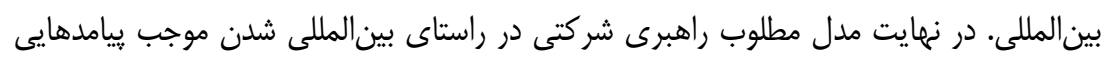

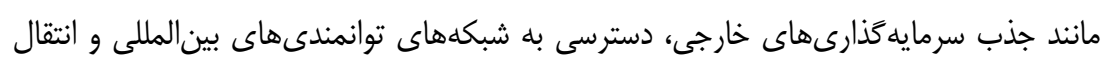

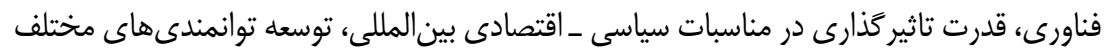

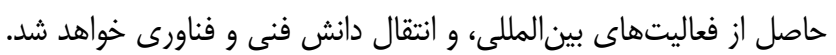


جدول ه: يافته هاى حاصل از مصاحبه با خبر كان در خصوص جارجوب مطلوب راهبرى شر كتى در شر كت ملّى نفت ايران

\begin{tabular}{|c|c|c|}
\hline فراوانى فر اوانى & مفاهم ثانه ده & مق له محص بـ \\
\hline اوليه اوليه & & \\
\hline
\end{tabular}

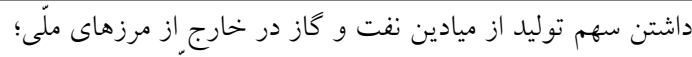

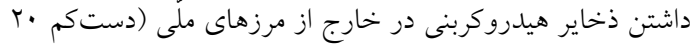

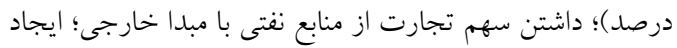

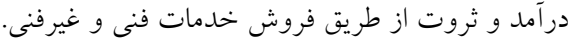

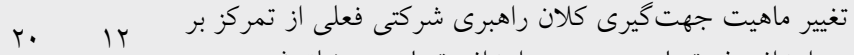

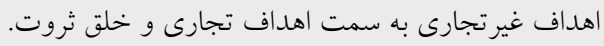

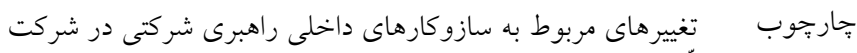

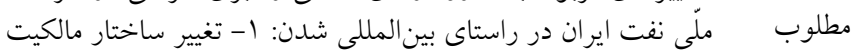

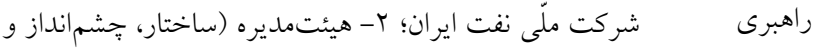

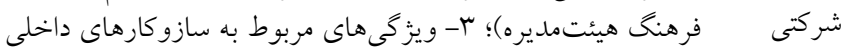

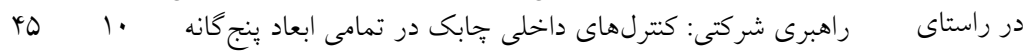

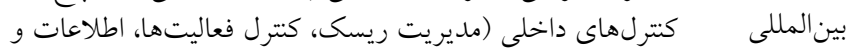

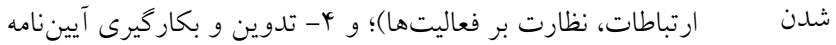

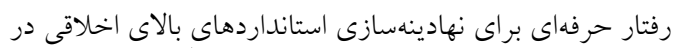

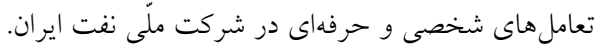

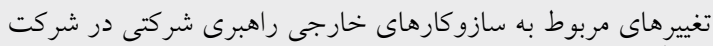

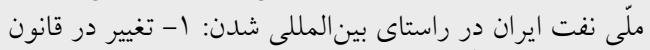

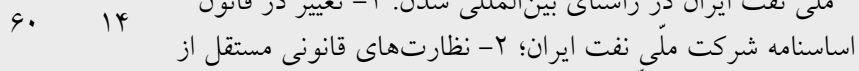

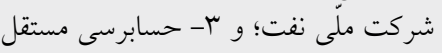




\section{نتايج حاصل از كدگذارى باز و محورى}

مقولههاى بلدستآمده از نتايج مصاحبه با خبر گان در جدول (ع) منعكس شده است.

جدول \&: ماتريس كيفى مقولههاى استخر اجى از مصاحبه با خبر كان

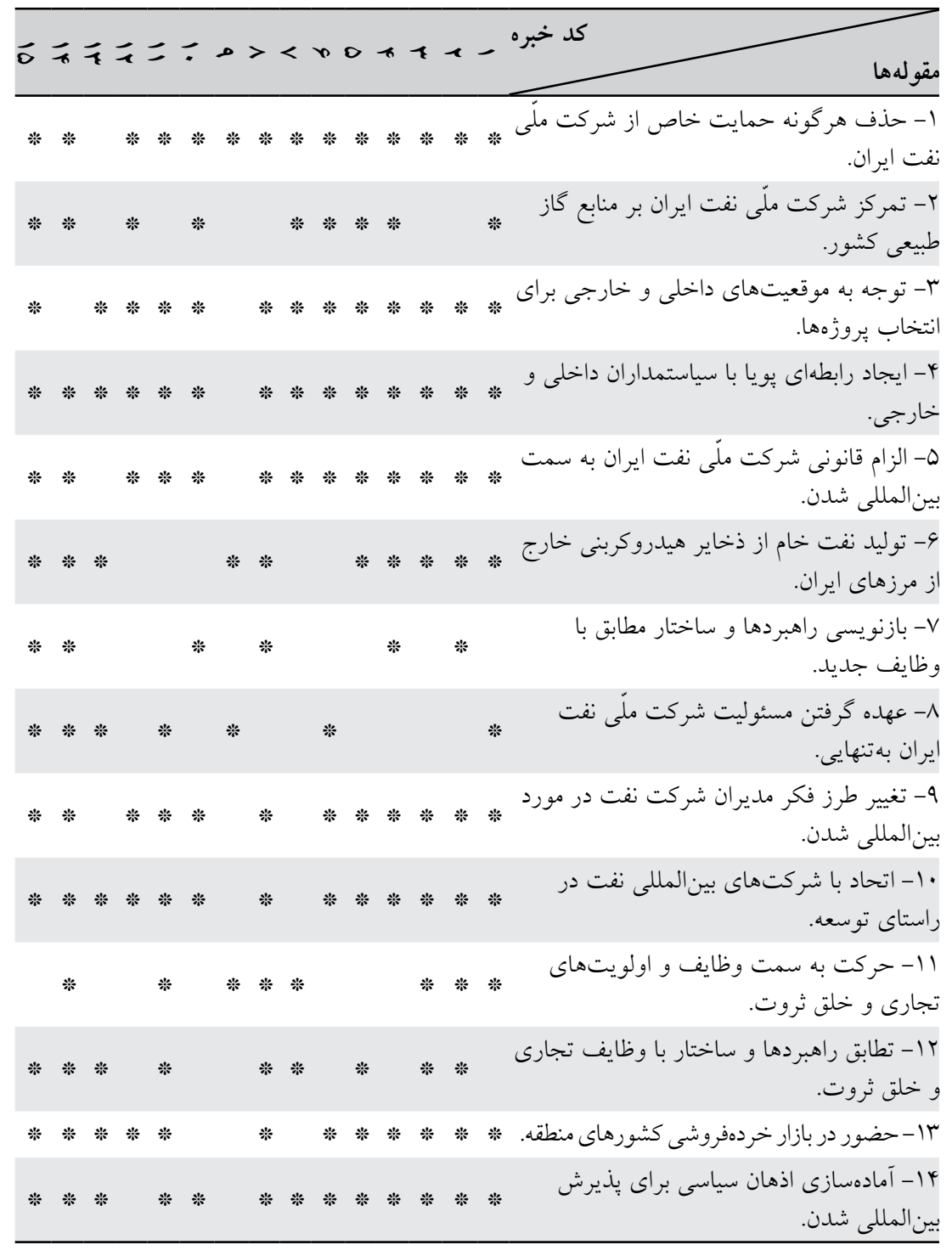

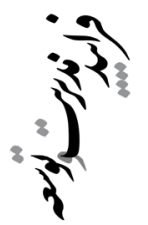

7
2
0
3
2
1
3
3
$\vdots 3$

$\sigma$

1
3
3
2
1
3
3
3

$\underline{2}$ 
ادامه جدول 9: ماتريس كيفى مقولههاى استخر اجى از مصاحبه با خبر كان

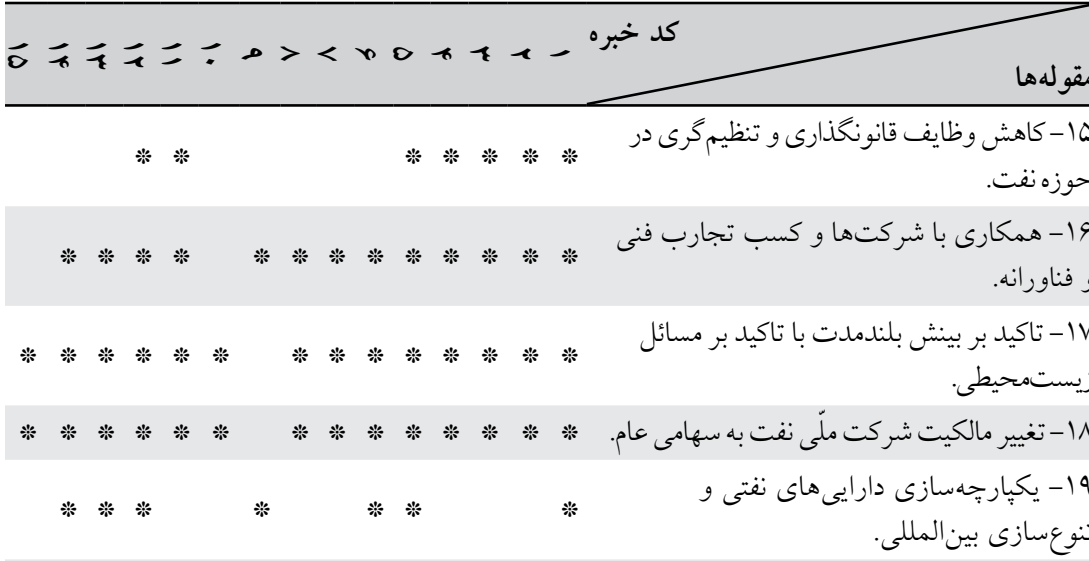
* * * * * * * * * * * * * * * * طبيعى

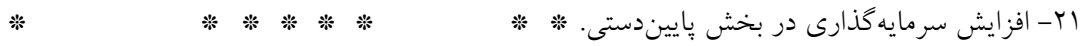
* * * * * * * * * * * * جذب متخصصان.

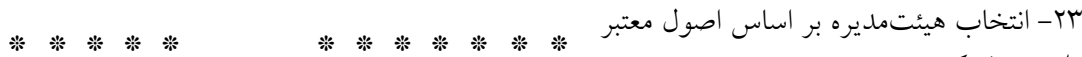
راهبرى شركتى.

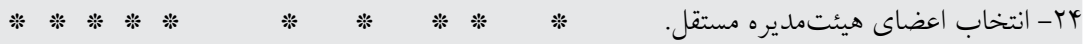
* * * * * * * * * * * * * * * * * هيئتمديره.

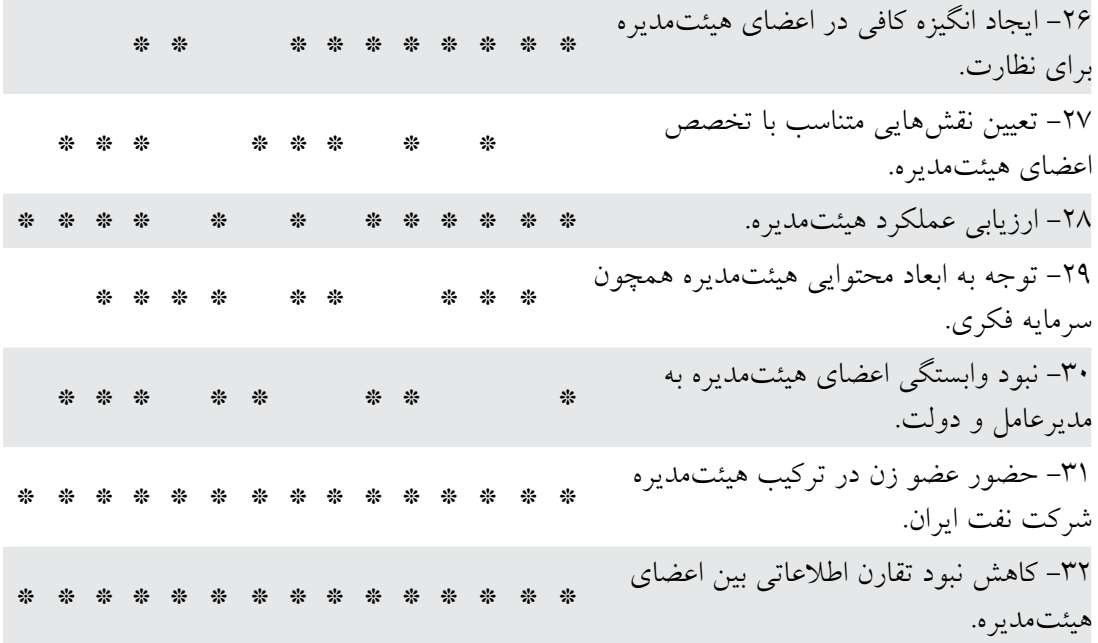


ادامه جدول \&: ماتريس كيفى مقولههاى استخر اجى از مصاحبه با خبر كان

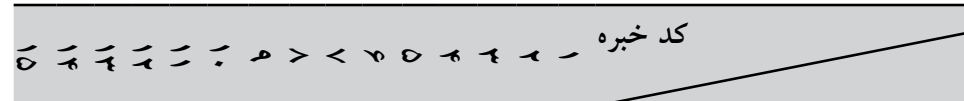

مقولهما

" هيئتمديره.

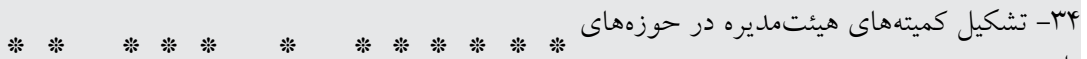
راهبردى. هـ هيئتمديره. 4

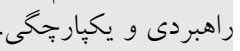

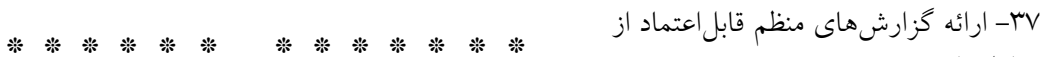
معامله هاى مهم.

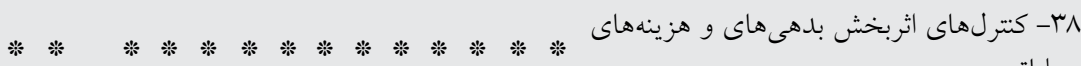
عملياتي.

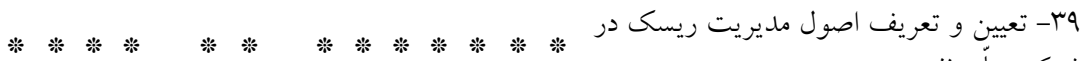

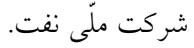

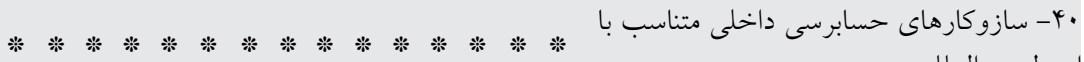

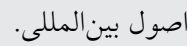
* * * * * * * * * * * * * اشخاص وابسته. * * * * * * * * * * * * * * * * * * * * * *

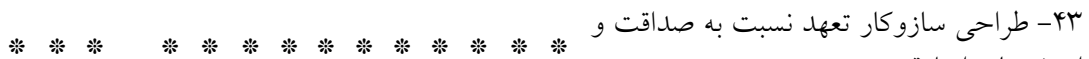
ارزشهاى اخلاقى.

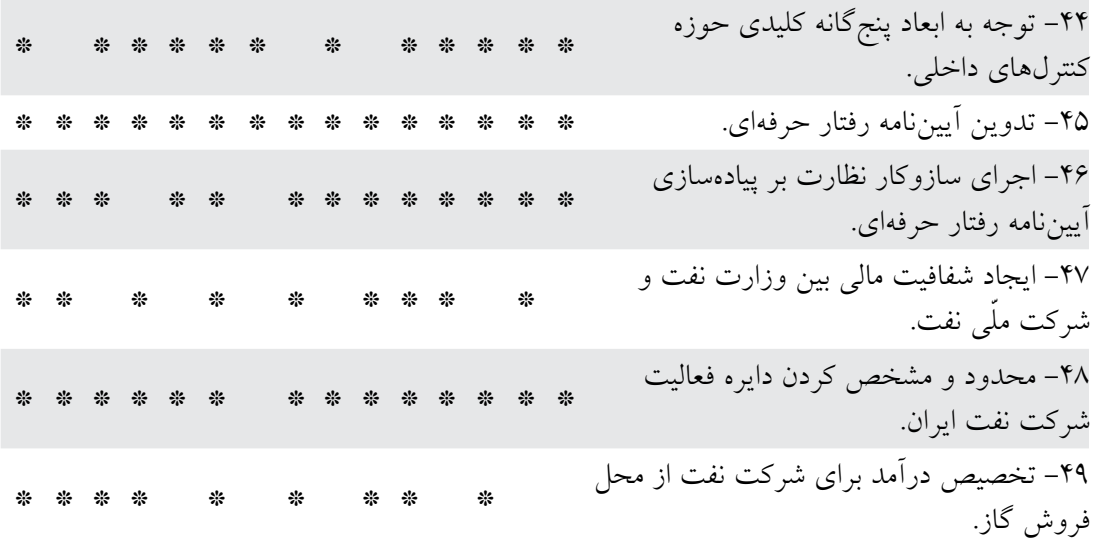


ادامه جدول 9: ماتريس كيفى مقولههاى استخر اجى از مصاحبه با خبر كان

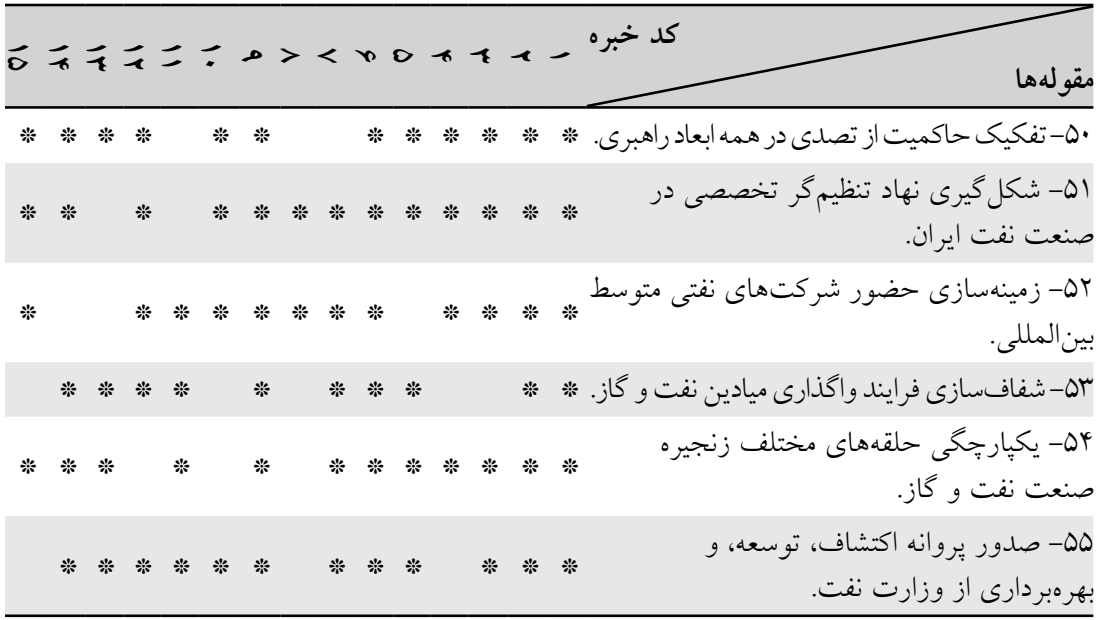

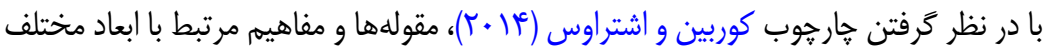
هارجوب بلهدست مى آيد كه نتايج آن در جدول (V) منعكس شده است.

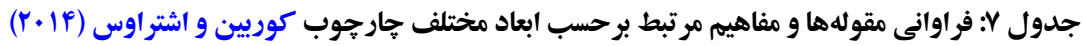

\begin{tabular}{|c|c|c|c|c|}
\hline كدراوانى & مفاهيم & مفاهيم ثانويه & مقولهها & جارجوب \\
\hline rI & 1. & صاهش قيمت نفت به دلايل مختلف انداز برابهام & صنعت نفت وض در جنده يران. & \\
\hline Ir & $\wedge$ & فناز به منابع مالى، دانش فنى، و & نياز به جذب در سرمايه كذارى & \\
\hline 10 & IT & مشترى، نوع فيزيكى ميادين مشترى ميادين. & ذخاير مشترى ايران در بهرهبردارى از & 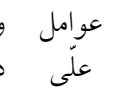 \\
\hline Yr & 1. & كربن، الزام به انرزى ڤهاى تجالش كاهش انتشار. & 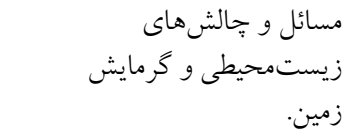 & \\
\hline TQ & Ir & 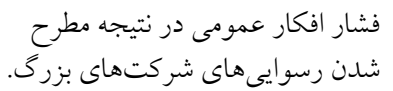 & رسوايى هاى متعدد در & \\
\hline
\end{tabular}


ادامه جدول Y:فراوانى مقولهها و مفاهيم مرتبط برحسب ابعاد مختلف جارجوب كوربين و اشتر اوس (1 • + )

\begin{tabular}{|c|c|c|c|c|}
\hline كراوانى & فراوانى & مفاهيم ثانويه & مقولهها & 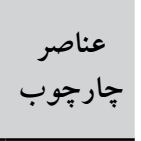 \\
\hline If & $\wedge$ & 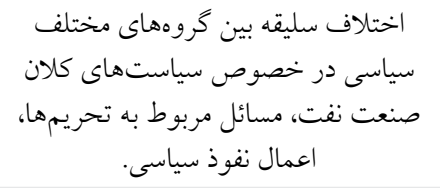 & جهت گيرى سياسى نفت. & \multirow{3}{*}{ مداخغيرهاى مئر } \\
\hline 10 & Ir & مر خدوديتهاى موجود ساختار مالكيت، نظام حقوقى ايران & جهت كيرى حقوقى نفت. & \\
\hline 11 & Ir & 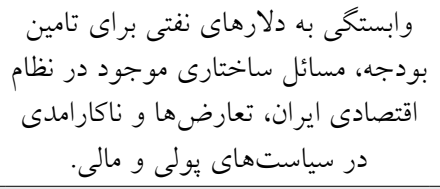 & جهت گيرى اقتصادى نفت. & \\
\hline TQ & 1. & 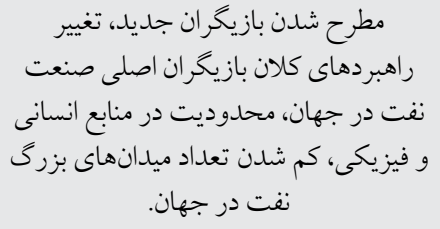 & فضاى ابررقابتى در صنعت & \multirow{3}{*}{ زمينائ } \\
\hline 14 & $\wedge$ & 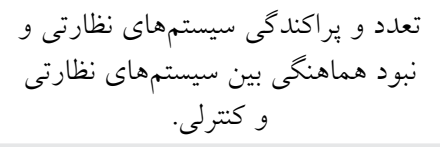 & سيستمهاى كنترلى حاد در & \\
\hline TQ & 10 & 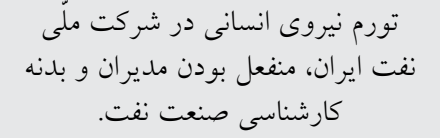 & فرهنگ انفعالى در صنعت & \\
\hline
\end{tabular}

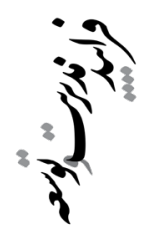

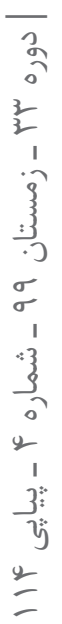




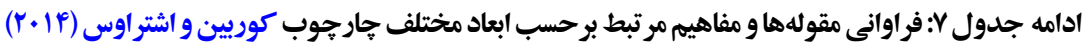

\begin{tabular}{|c|c|c|c|c|}
\hline فراوانى & فراوانى & مفاهيم ثانويه & مقولهها & جارجوب \\
\hline YI & 11 & غيرتجارى و جوازن ميان اهداف تجارى و برى خلق & تغيير الكوى كلان راهبرى & \multirow{3}{*}{ محورى مقله } \\
\hline 11 & 9 & 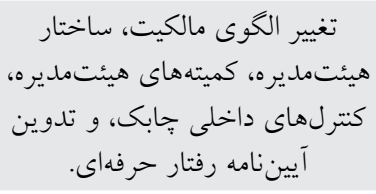 & 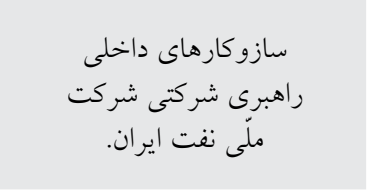 & \\
\hline 9 & r & 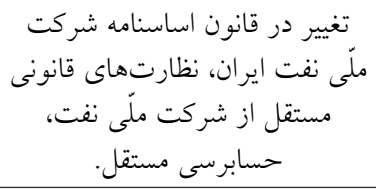 & سازو كارهاى خارجى شتى & \\
\hline TY & 1. & 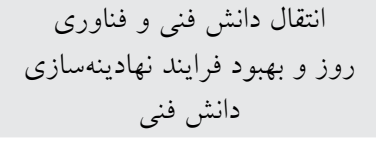 & تو انمندى هاى به بين المللى. & \multirow{3}{*}{ 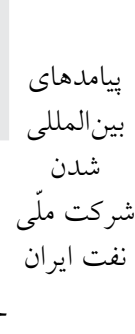 } \\
\hline TQ & 10 & استفاده از ظرفيتهاى سياسى & 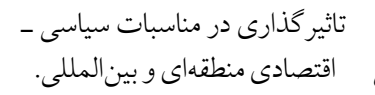 & \\
\hline TH & $\pi$ & توسعه و بهبود توان مديريت & حاصل از فعاليته توانمندى هاى خارج مختلف از مرزها. & \\
\hline
\end{tabular}

\section{شكل گيرى نظريه}

برخى از يروهشگران مرحله كدكذارى انتخابى را آخرين مرحله براى مدلسازى نمىدانند. اين مرحله نسبت به مرحله كدگذارى انتخابى يا را فراتر مى گذارد و سعى در شناسايى روابط بين مقولهها دارد تابر اساس اين ضمن ايجاد نظريه كاملتر، مدل نهايى استخراج گرددد. در اين مرحله، يزوهشخَران با يالايش يافتههاى ييشين و با طى فرايندهاى رفت و برَشت روى دادهها ودستاوردهاى يزوهش در مراحل قبل، به دنبال شناسايى ارتباط بين مقولهها هستند. اين ارتباطات در نظريئ ساختهشده به شكل قضيdهايى بيانيذير هستند. قضيههاى استخراجشده كه در مدل به شكل ارتباط ميان مقولهها نشان داده مىشود را مىتوان به شكل فرضيه در آزمون مدل استخراجشده مورد اندازهيرى قرار داد. بايد توجه داشت ساختن و تدوين مفاهيه، مقولهها و قضيهها در نظريه مبناى ديخر مفاهيم است. 


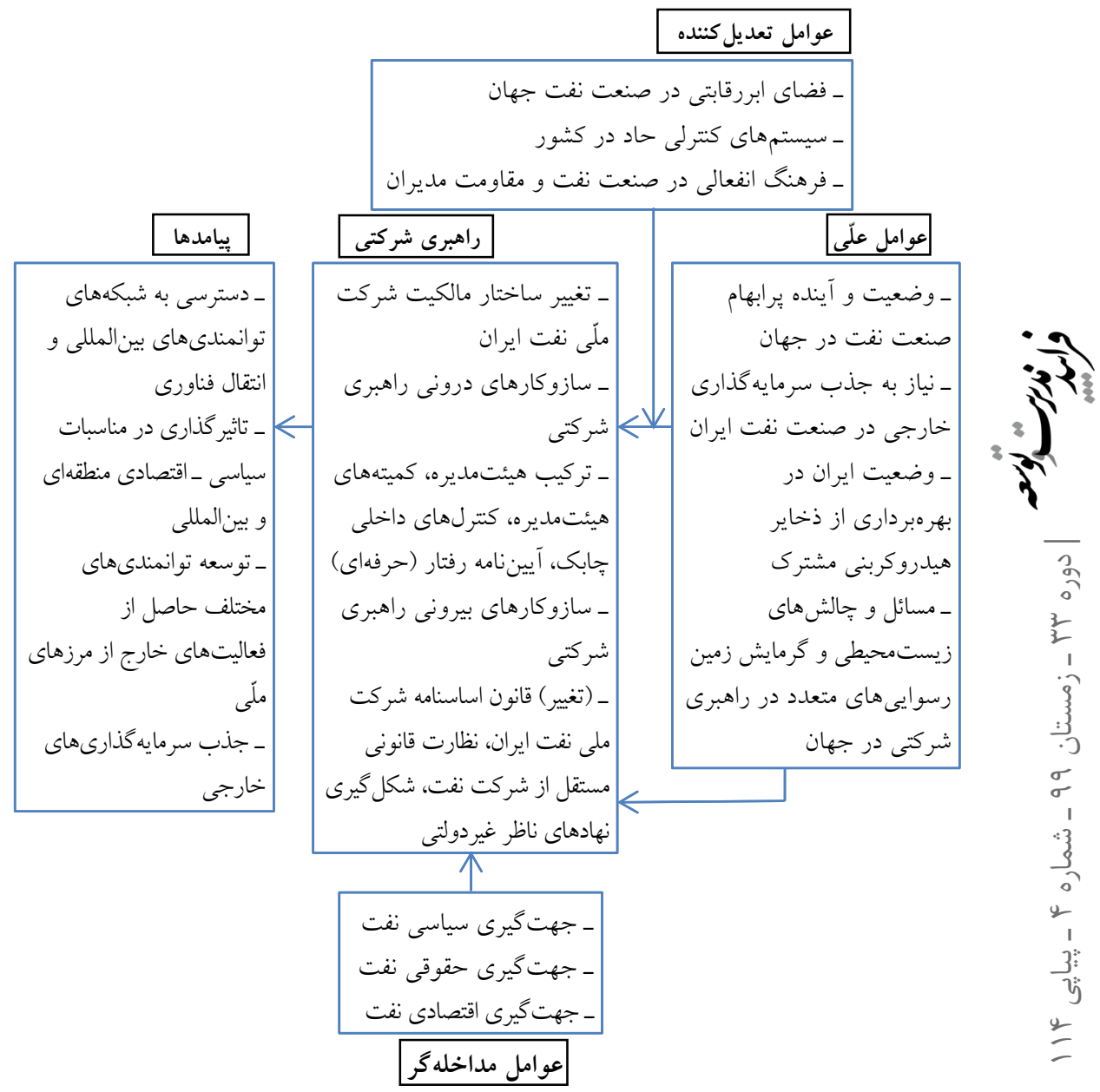

شكل ז: جارجوب مطلوب راهبرى شر كتى براى شر كت ملّى نفت ايران در راستاى بينالمللى شدن

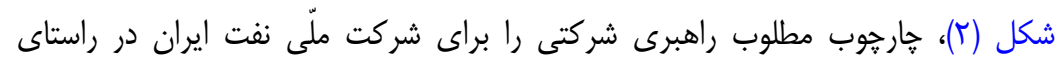

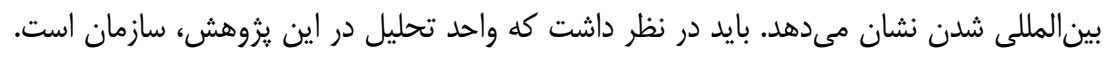

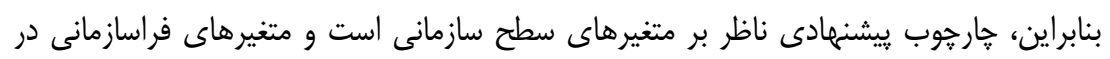
اين خار خوب لحاظ نشده است. 


\section{ساز كارى يافتهها با مبانى نظرى}

هرجند يافتهاى اين يزوهش در مقايسه با مبانى نظرى يِيش كَته از نوآورى و جامعيت بيشترى برخوردار است و حاصل روايت خبركان يزوهش حاضر از فرايند بينالمللى شدن و

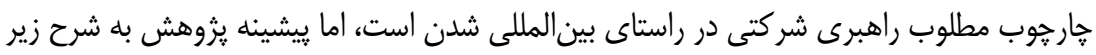
با برخى از يافتهاى اين يزوهش ساز كارى دارد:

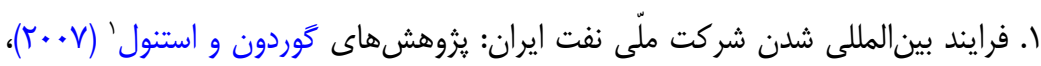

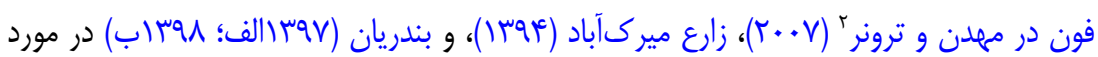

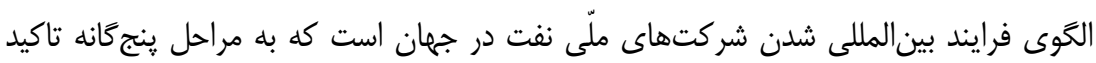

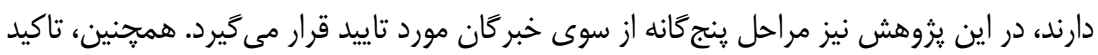

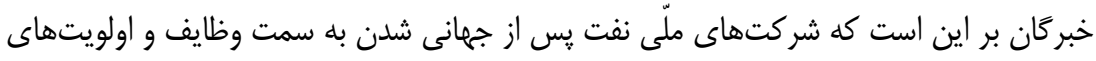

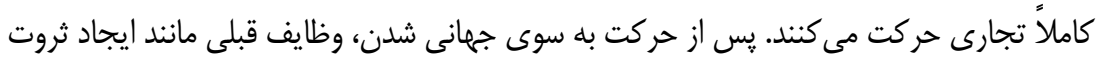

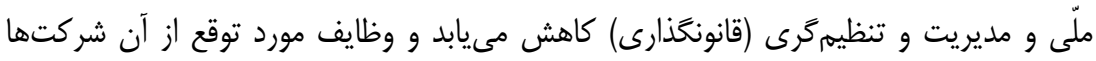

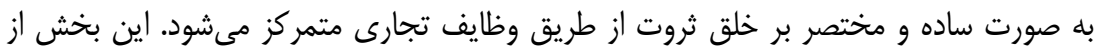

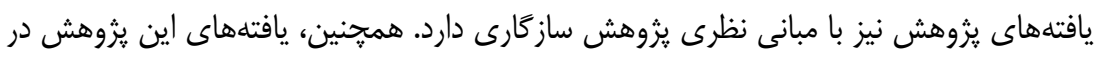

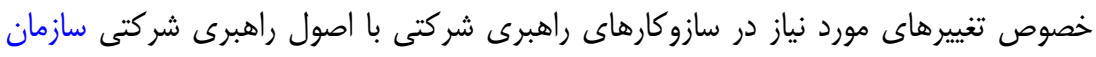

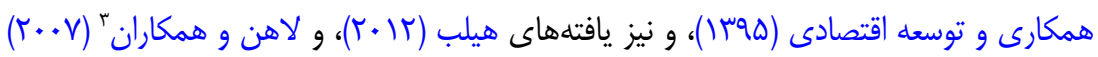
در مورد ويثگى هاى مطلوب هيئتمديره در رويكرد راهبرى شركتى نوين ساز كارى دارد. همجئنين،

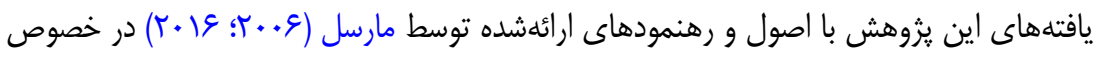
رهنمودهايى براى حاكميت خوب در بخش نفت و كاز در كشورهاى نوظهور توليدكننده نفت و كاز نيز ساز كارى دارد. r. عوامل علّى: تلاش در رقارد بابت با شركتهاى جديد، كسب بازارهاى مناسب، حضور در

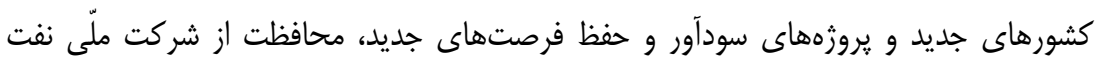

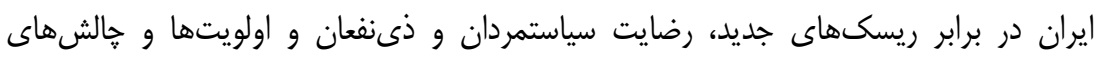
جديد زيستمحيطى و نيز انرزىهاى تجديديذير، كسب مهارتهاى نو و فعاليتهاى فناورانه

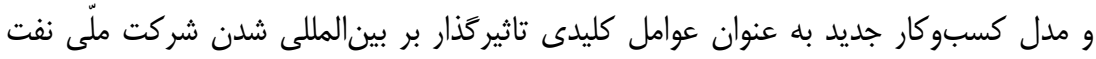

1. Gordon \& Stenvoll

2. Von der Mehden \&Troner

3. Lahn et al. 


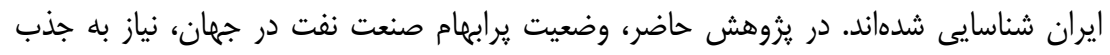

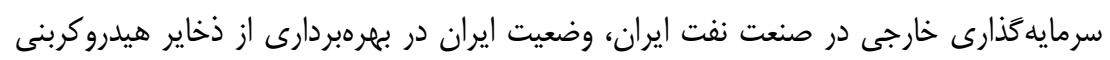

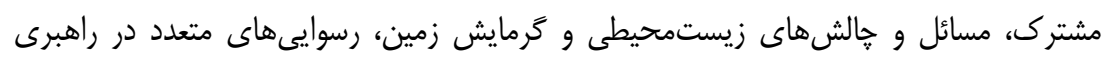

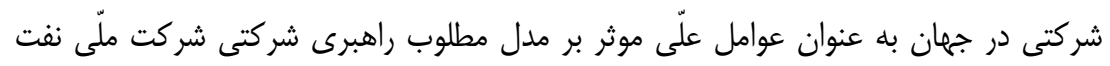

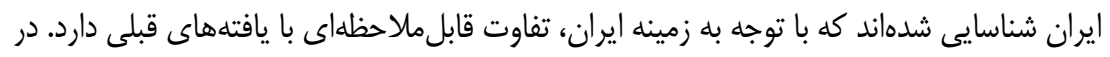

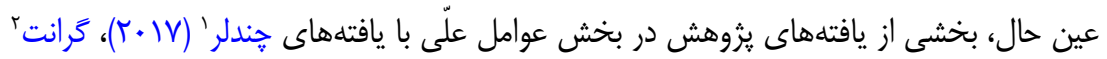

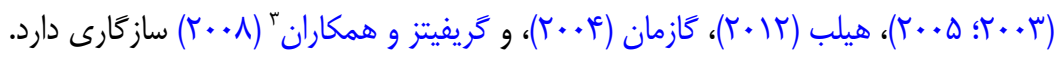

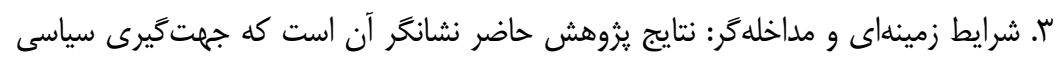

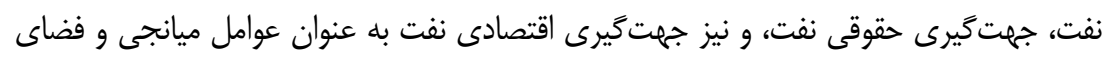

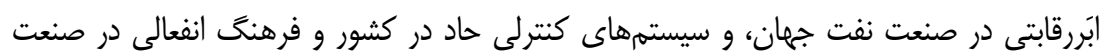

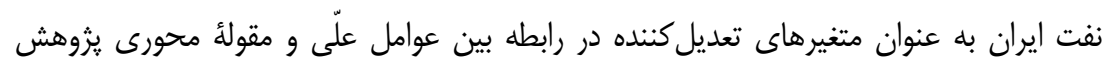

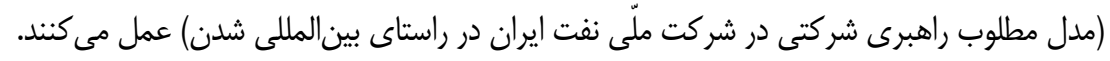

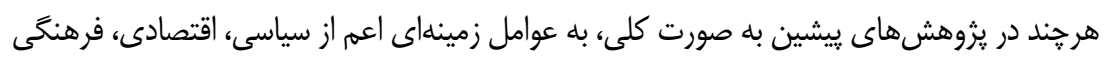

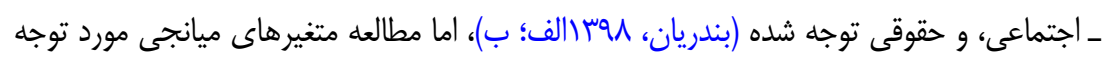

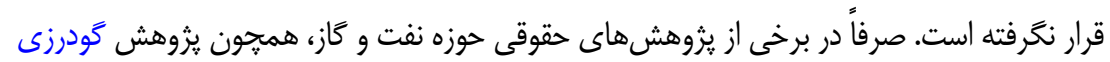

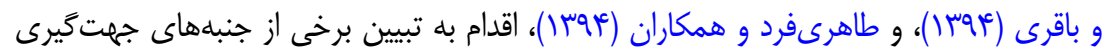

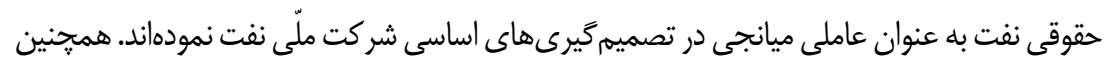

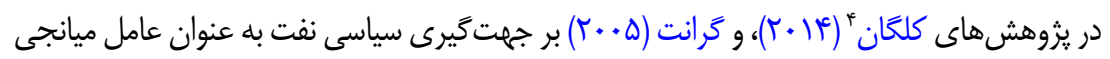

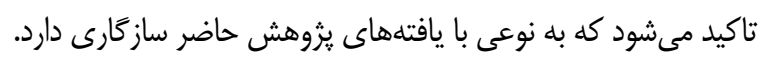

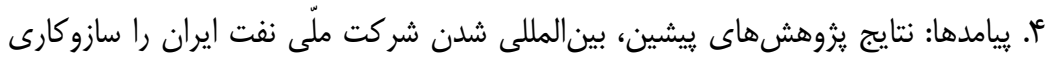

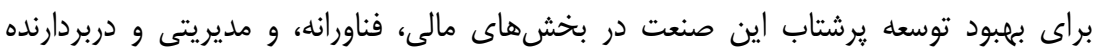

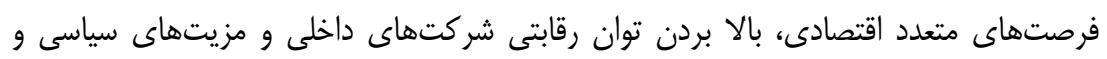

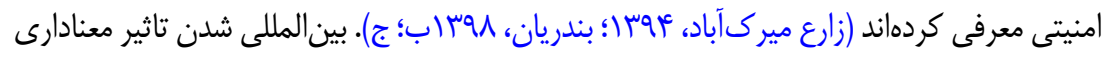

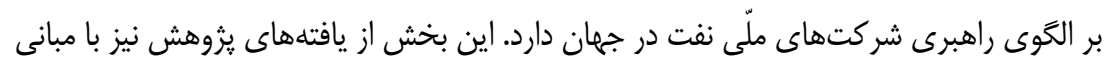

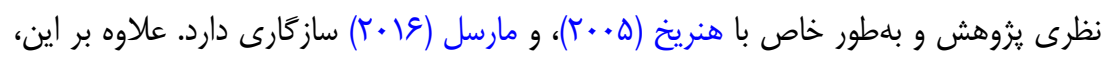

1. Chandler

2. Grant

3. Griffiths et al.

4. Colgan 
نتايج اين يزوهش نشانكر آن است كه جذب سرمايه كذارىهاى خارجى، دسترسى به شبكههاى توانمندى هاى بين المللى، تاثير كذارى در مناسبات سياسى ـ اقتصادى، توسعه توانمندى هاى حانى حاصل

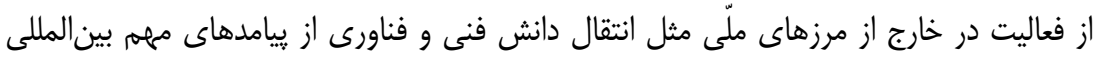

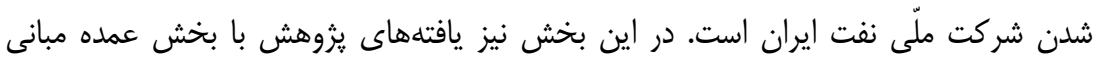

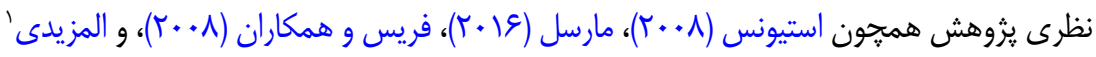

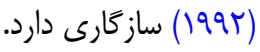

\section{بحث و نتيجه كيرى}

با توجه به تغيير شرايط محيطى در صنعت نفت جهان، شركت ملّى نفت ايران در حال كذر

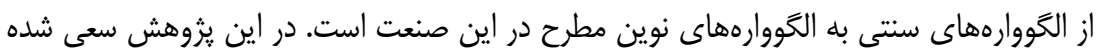

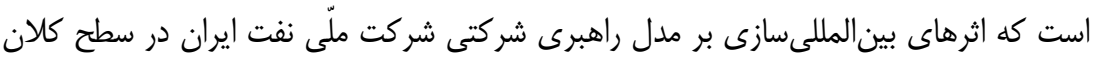
مورد تحليل و بررسى قرار كيرد و جنبههاى كليدى راهبرى شركتى را به هم ييوند دهد. با توجنه

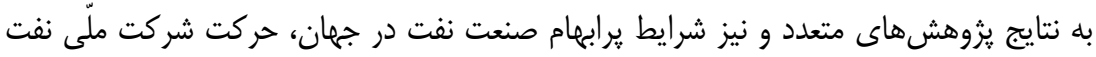
ايران به سوى بينالمللى شدن ضرورى است. در راستاى حركت به سمت بينالمللى شدن، شركت

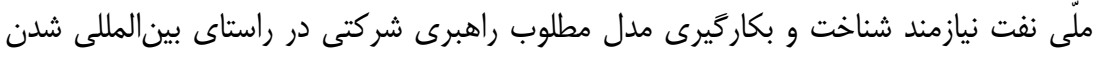

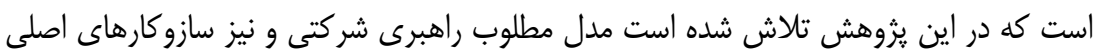

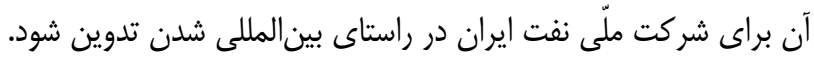

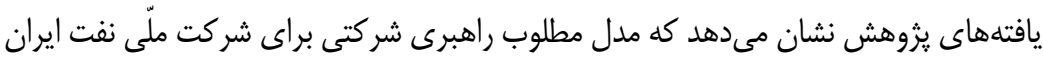

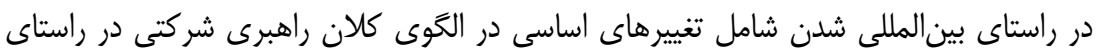

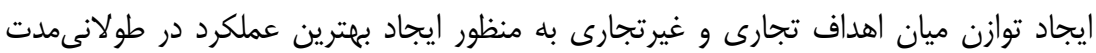

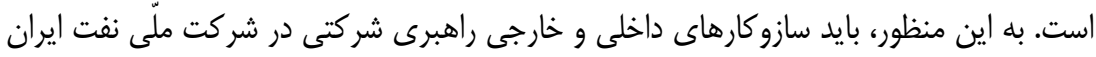

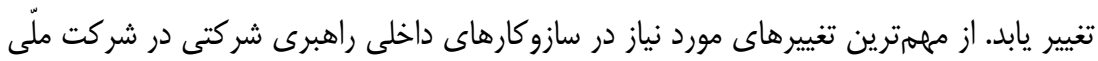

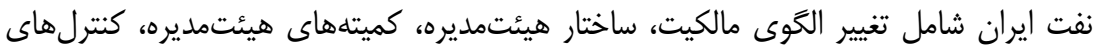

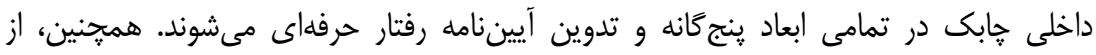

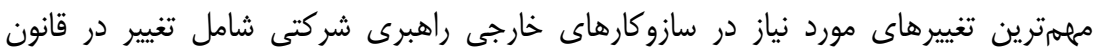

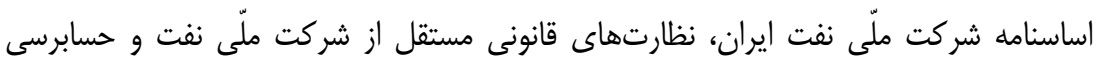

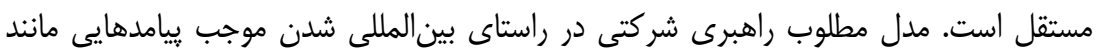

1. Al-Mazeedi 
جذب سرمايه كذارىهاى خارجى، دسترسى به شبكههاى توانمندى هاى بينالمللى و انتقال فناورى،

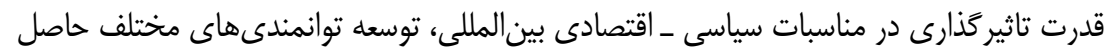

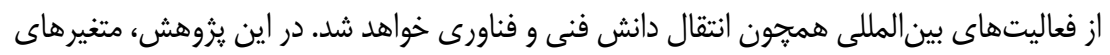

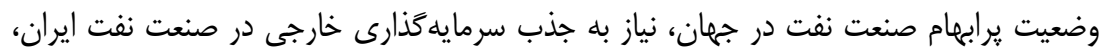

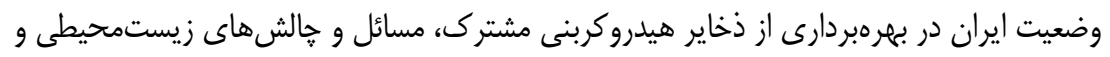

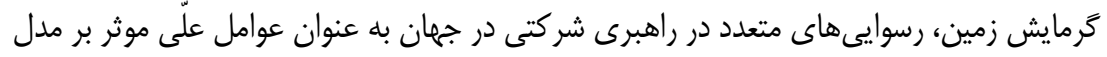

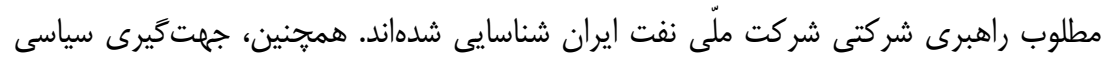

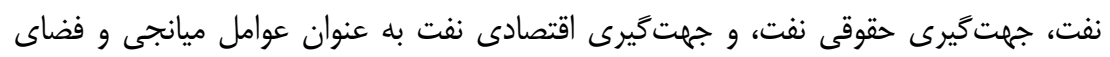

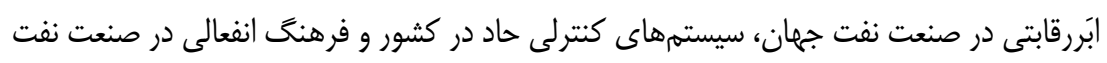

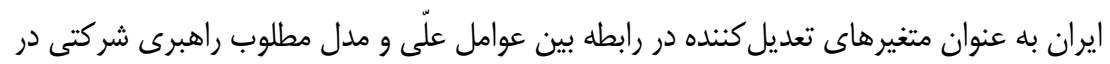

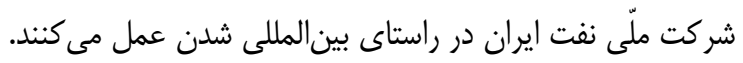

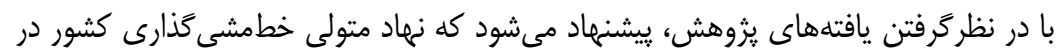

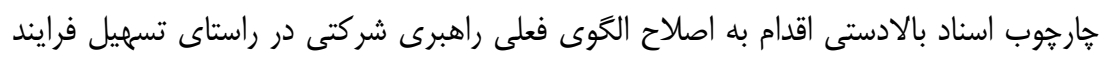

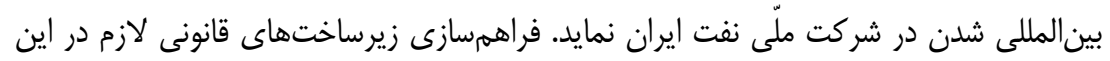

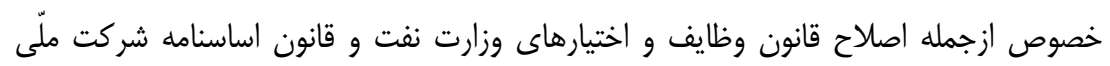

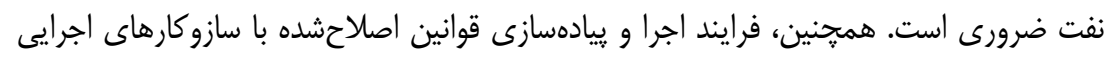

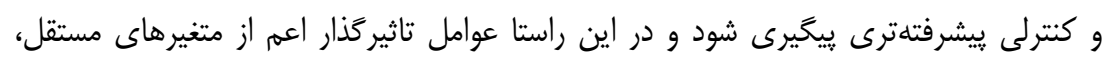

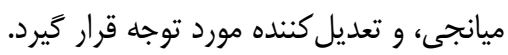

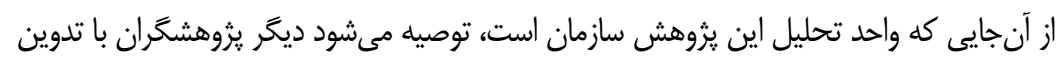

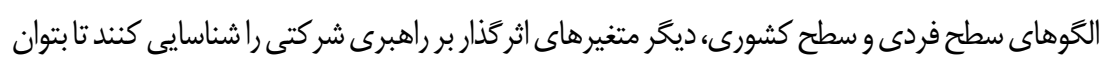

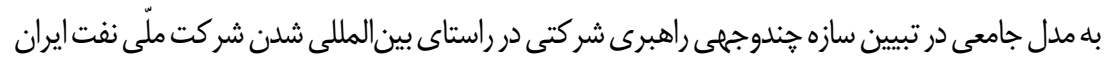

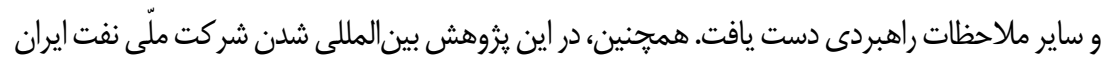

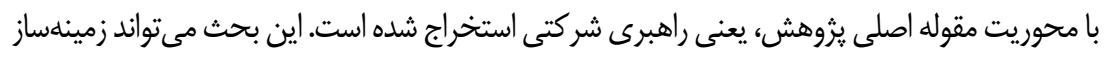

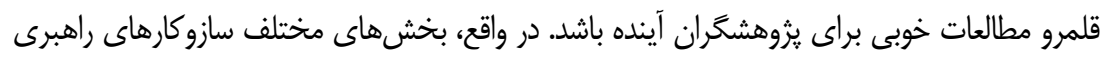

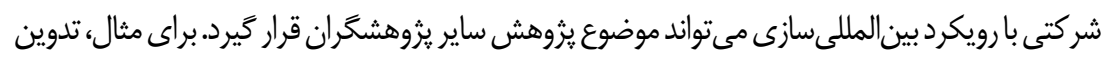

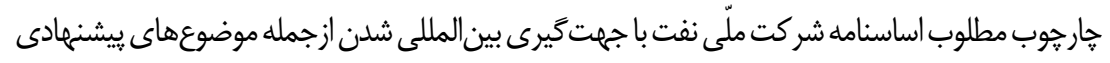

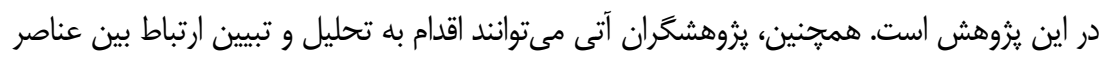

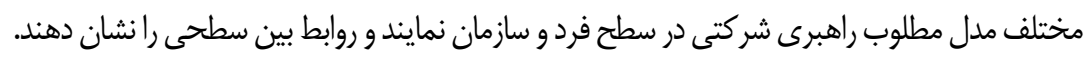




\section{منابع}

الف) فارسى (الفى

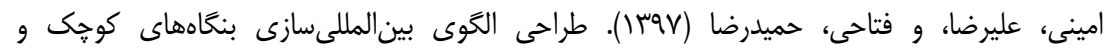

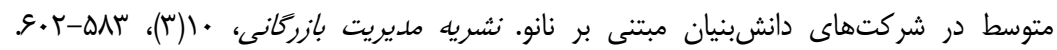
https://dx.doi.org/10.22059/jibm.2018.253543.2972

بندريان، رضا (Vوجا الف). لزوم بين المللى شدن صنعت نفت ايران و جايخاه فناورى در تحقق آن.نشريهاكتشاف

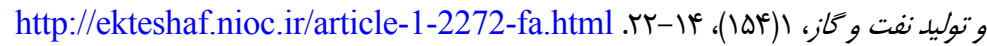

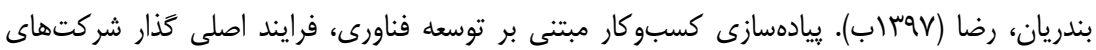

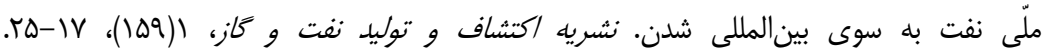
http://ekteshaf.nioc.ir/article-1-2399-fa.html

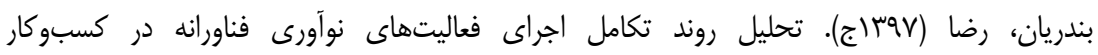

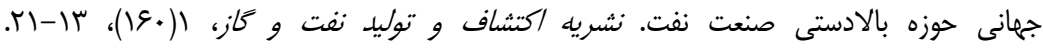
http://ekteshaf.nioc.ir/article-1-2428-fa.html

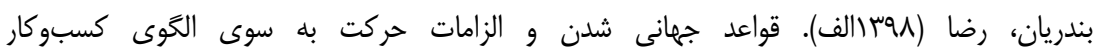

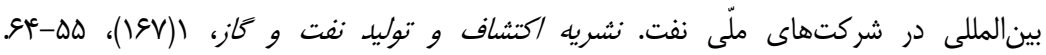
http://ekteshaf.nioc.ir/article-1-2626-fa.html

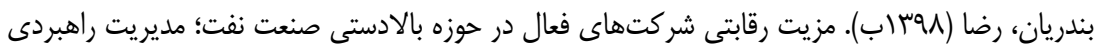

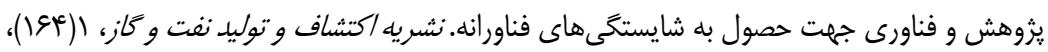
http://ekteshaf.nioc.ir/article-1-2543-other.html بار

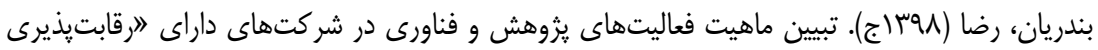

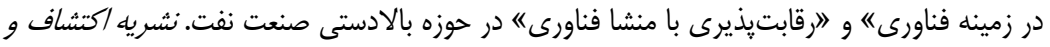

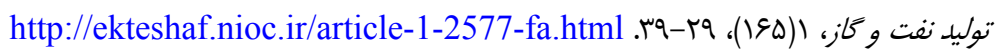

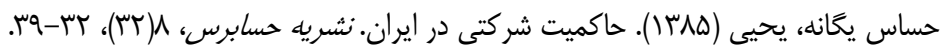

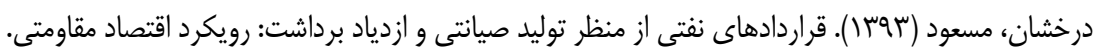

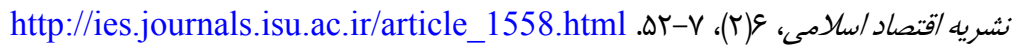

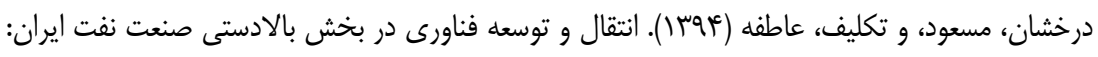

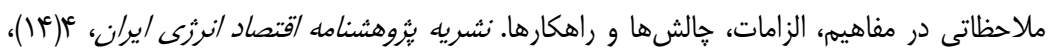

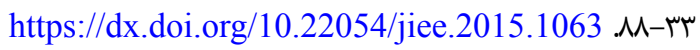

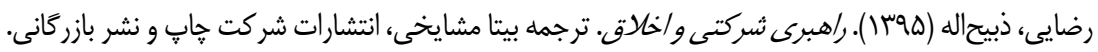

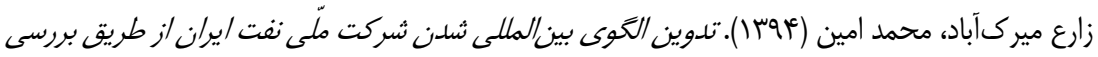

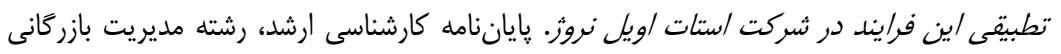
دانشكده مديريت دانشخاه تهران. سازمان همكارى و توسعه اقتصادى (هوبr). اصول راهبرى شركتى سازمان همكارى و توسعه اقتصادى. 


$$
\begin{aligned}
& \text { ترجمأُ شاهين احمدى، انتشارات بورس وابسته به شركت اطلاعرسانى و خدمات بورس. }
\end{aligned}
$$

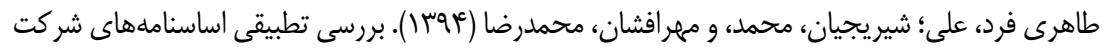

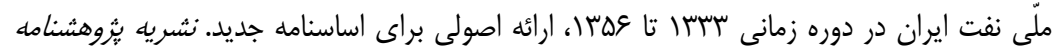

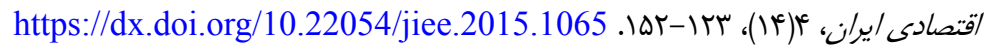

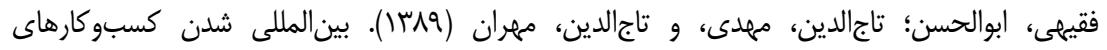

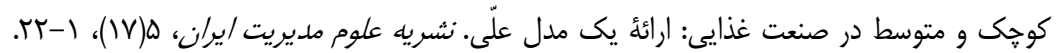

$$
\begin{aligned}
& \text { http://journal.iams.ir/article_47.html }
\end{aligned}
$$

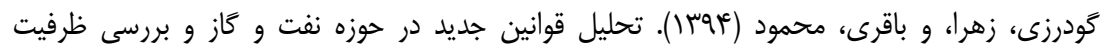

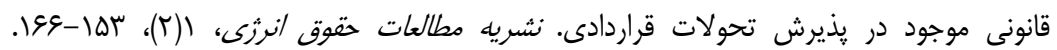

$$
\begin{aligned}
& \text { https://dx.doi.org/10.22059/jrels.2015.57208 }
\end{aligned}
$$

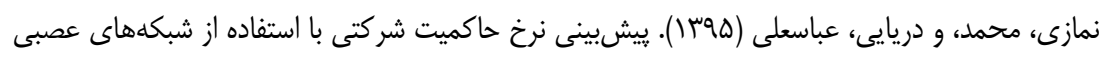

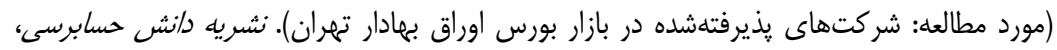

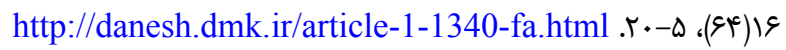

هيلب، مارتين (هوسا). نغاهى نو به حاكميت شركتى: /بز/رهايى براى موفقيت هيئتمديره. ترجمه محمدعلى شاهحسينى و محمدهادى رنجبر، انتشارات دانشعاه تهران.

Al-Mazeedi, W. (1992). Privatizing National Oil Companies in the Gulf. Energy Policy, 20(10), 983-994. https://doi.org/10.1016/0301-4215(92)90186-6

Andersen, O. (1993). On the Internationalization Process of Firms: A Critical Analysis. Journal of International Business Studies, 24(2), 209-231. https://doi.org/10.1057/palgrave.jibs.8490230

Banasadegh, Z., Zahedi, S., \& Farjadi, G. (2020). A Model for Development Planning Process Based on the Sustainable Development Approach in the Iranian Oil Industry. Quarterly Journal for Management and Development Process, 33(3), 95-128. http://jmdp.ir/article-1-3772-fa.html

Beamish, P. W. (1990). The Internationalization Process for Smaller Ontario Firms: A Research Agenda. Research in Global Business Management, 1(1), 77-92.

Calof, J. L., \& Beamish, P. W. (1995). Adapting to Foreign Markets: ExplainingInternationalization.InternationalBusinessReview, 4(2), 115-131. https://doi.org/10.1016/0969-5931(95)00001-G

Chandler, J. (2017). Stewardship of Offshore Petroleum: Where is the Value? Marine Policy, 81(1), 64-70. https://doi.org/10.1016/j.marpol.2017.03.015

Charmaz, K. (2006). Constructing Grounded Theory: A Practical Guide through Qualitative Analysis: Sage Publications. 
Colgan, J. D. (2014). Oil, Domestic Politics, and International Conflict. Energy Research \& Social Science, 1(1), 198-205. https://doi.org/10.1016/j.erss.2014.03.005

Corbin, J., \& Strauss, A. (2014). Basics of Qualitative Research: Techniques and Procedures for Developing Grounded Theory: Sage Publications.

Friess, B., Baumgartner, R. J., \& Bauer, G. (2008). Success Factors of Petroleum Exploration and Production Companies. International Journal of Services and Operations Management, 4(2), 145-164. https://doi.org/10.1504/IJSOM.2008.016608

Gordon, R., \& Stenvoll, T. (2007). Statoil: A Study in Political Entrepreneurship. The Changing Role of National Oil Companies in International Energy Markets.

Grant, R. (2005). Oil Company Strategies from 1970 to the Present. Encyclopaedia of Hydrocarbons, 4(1), 301-321.

Grant, R. M. (2003). Strategic Planning in a Turbulent Environment: Evidence from the Oil Majors. Strategic Management Journal, 24(6), 491517. https://doi.org/10.1002/smj.314

Griffiths, M., O'callaghan, T., \& Roach, S. C. (2008). International Relations: The Key Concepts: Taylor \& Francis.

Guzman, A. T. (2004). Global Governance and the WTO. Boalt Working Papers in Public Law.

Guzman, R., Carvajal, P., \& Kinbaum, A. (2019). Internationalization of National Oil Companies. https://www.adlittle.com/en/NOC_Internationalization.

Heinrich, A. (2005). Why Corporate Governance in the Russian Oil and Gas Industry is Improving. Corporate Governance: The International Journal of Business in Society, 5(4), 3-9. https://doi.org/10.1108/14720700510616550

Hilb, M. (2012). New Corporate Governance: Successful Board Management Tools: Springer Science \& Business Media.

James, R. A. (2011). Strategic Alliances between National and International Oil Companies. Paper Presented at the Pillsbury Energy Conference, Lansdowne, Virginia.

Kalafsky, R. V. (2009). Export Challenges and Potential Strategies: Canadian Manufacturers in the Chinese Market. Journal of Small Business and Enterprise Development, 16(1), 47-59. https://doi.org/10.1108/14626000910932872

Kheir-andish, M., Zare'a, M., \& Mokhtari, M. (2018). An Infrastructural Model for Internationalization of Iranian National Oil Company: An Exploratory and Comparative Study for Proposing a Transformational Path. Quarterly Journal for Management and Development Process, 31(2), 6590. http://jmdp.ir/article-1-2721-en.html

kumar, P., \& Reshma, R. (2018). Corporate Governance Practices in Petroleum 
Sector. IOSR Journal of Engineering, 8(11), 70-73.

Lahn, G., Marcel, V., Mitchell, J., Myers, K., \& Stevens, P. (2007). Good Governance of the National Petroleum Sector. The Chatham House.

Ledesma, D. (2009). The Changing Relationship between NOCS and IOCS in the LNG Chain. Oxford Institute for Energy Studies NG 32.

Marcel, V. (2006). Oil Titans: National Oil Companies in the Middle East: Brookings Institution Press.

Marcel, V. (2016). Guidelines for Good Governance in Emerging Oil and Gas Producers 2016. Research Paper, Chatham House.

McPherson, C. (2004). National Oil Companies-Evolution, Issues, Outlook. Oil, Gas \& Energy Law Journal (OGEL), 2(2), 1-24.

Mishra, N. (2015). Corporate Governance in Russia. in Corporate Governance, Responsibility and Sustainability (pp. 91-116): Springer. https://doi.org/10.1057/9781137361851_6

Mitchell, J. V., Marcel, V., \& Mitchell, B. (2012). What Next for the Oil and Gas Industry?: Chatham House London.

Rundh, B. (2007). International Marketing Behaviour Amongst Exporting Firms. European Journal of Marketing, 41(1/2), 181-198. https://doi.org/10.1108/03090560710718175

Searle, R. (2010). Corporate Governance in the Major Oil and Gas Companies: University of Massachusetts, Lowell, United States of America (USA).

Stevens, P. (2003). National Oil Companies: Good or Bad. A Literature Survey. National Oil Companies Workshop Current Roles and Future Prospects World Bank.

Stevens, P. (2008). National Oil Companies and International Oil Companies in the Middle East: Under the Shadow of Government and the Resource Nationalism Cycle. Journal of World Energy Law \& Business, 1(1), 5-30. https://doi.org/10.1093/jwelb/jwn004

Stevens, P. (2015). Prospects for Iran's Oil and Gas Sector: Chatham House for the Royal Institute of International Affairs.

Tordo, S. (2011). National Oil Companies and Value Creation: The World Bank. Von der Mehden, F. R., \& Troner, A. (2007). Petronas: A National Oil Company with an International Vision. Baker Institute for Public Policy, Rice University, Houston.

Welch, L. S., \& Luostarinen, R. (1988). Internationalization: Evolution of a Concept. Journal of General Management, 14(2), 34-55. https://doi.org/10.1177/030630708801400203 